Volume 12

Issue 2 Images And Collective Violence:

Function, Use And Memory

Article 10

$10-2018$

\title{
Challenging Old and New Images Representing the Cambodian Genocide: The Missing Picture (Rithy Panh, 2013)
}

Vicente Sánchez-Biosca

University of Valencia

Follow this and additional works at: https://digitalcommons.usf.edu/gsp

\section{Recommended Citation}

Sánchez-Biosca, Vicente (2018) "Challenging Old and New Images Representing the Cambodian Genocide: The Missing Picture (Rithy Panh, 2013)," Genocide Studies and Prevention: An International Journal: Vol. 12: Iss. 2: 140-164.

DOI:

https://doi.org/10.5038/1911-9933.12.2.1508

Available at: https://digitalcommons.usf.edu/gsp/vol12/iss2/10

This Articles is brought to you for free and open access by the Open Access Journals at Digital Commons @ University of South Florida. It has been accepted for inclusion in Genocide Studies and Prevention: An International Journal by an authorized editor of Digital Commons @ University of South Florida. For more information, please contact digitalcommons@usf.edu. 


\section{Challenging Old and New Images Representing the Cambodian Genocide: The Missing Picture (Rithy Panh, 2013)}

\section{Acknowledgements}

I would like to thank the respective directors, Chhay Visoth, Youk Chhang and Rithy Panh for providing access to the material, as well as Helen Jarvis for facilitating access to the Tuol Sleng archives. I am also grateful for the enlightening conversations in New York with Deirdre Boyle in the Winter-Spring 2017 and to Stéphanie Benzaquen-Gautier and Anne-Laure Porée for sharing a common project on Tuol Sleng. 


\section{Challenging Old and New Images Representing the Cambodian Genocide: The Missing Picture (Rithy Panh, 2013)}

Vicente Sánchez-Biosca

University of Valencia

Valencia, Spain

\section{Introduction $^{1}$}

This article focuses on the images used over four decades to represent the Cambodian genocide in photography, cinema, visual arts and the media as the basis for analyzing the documentary-memoir directed by Rithy Panh, L'image manquante (The Missing Picture). ${ }^{2}$ There is a paucity of surviving images which depict, evoke or allude to the crimes perpetrated by the Khmer Rouge (1975-1979), and, even more importantly, objections raised by scholars - especially Holocaust researchers about whether any image can adequately depict a catastrophic event such as genocide. So, this essay begins by categorizing the Cambodian genocide iconography according to the modality of the visual production, that is, the relationship between the gaze that captures the pictures and the object depicted in them. After briefly describing the stylistic and ethical perspective of this visual output (classified in four basic categories: perpetrator images, liberator images, belated evidential images, and creative imagery), this article questions the challenging visual strategies used in The Missing Picture. Panh, who dedicated his entire career to searching for, restoring, collecting and inscribing images representing the crimes related to Pol Pot's regime, adopts an unexpected and original dispositif in his 2013 documentary: an un-realistic imagery based on hand-carved clay figurines placed in a diorama-like setting, as the narrative is sustained by a first-person hypnotic voiceover that evokes the author's childhood memories under the Khmer Rouge rule. By juxtaposing these static figures with propaganda archival footage, Panh introduces an estrangement that paradoxically imbues the film continuum with an emotional tone ideal for conveying affliction. From a figurative perspective, this device avoids mimesis and draws upon a tradition of "animal stories" combined with animation techniques and other distancing strategies which echo in cinema language the animal-like figures used by Art Spiegelman to recount his father's experiences in Auschwitz. ${ }^{3}$ Beyond a representational point of view, the originality of The Missing Picture draws on the search of a visual and narrative vocabulary destined to perform an exorcism from trauma; or, from another perspective, a self-therapeutic exercise through art and memory work.

\section{Suspect Images: Ideology and Imagination}

In what was presented as the first reportage shot in Cambodia by "Westerners" after the defeat of the Khmer Rouge, ${ }^{4}$ the renowned investigative journalist John Pilger, from The Daily Mirror, underscored the paradox that in a world of media saturation, there had been a total absence of news about this small country for almost four years and, in particular, no coverage at all of the Khmer Rouge genocide. Certainly, this was not the first time that a media reporter had brought the world's attention to the hermetic circle of silence which had protected Democratic Kampuchea from April 1975 until the end of the regime in January 1979. In any case, this new vacuum contributed to creating an atmosphere of uncertainty that only imagination or, more commonly, ideology were capable of fulfilling. More to the point, amidst a universe of omnipresent images, this news blackout brought to the fore the dearth of visual material.

The radical Khmer Rouge regime had of course been mentioned in the leftwing press and in the circles of small but fiercely active Maoist groups scattered around the globe that channeled the anti-American sentiment, which had surfaced during the Vietnam war. Meanwhile, some

\footnotetext{
${ }^{1}$ This article has been conceived in the framework of the research project "Contemporary Representations of Mass Violence Perpetrator: Concepts, Narratives, and Images" (HAR2017-83519-P). The research for this essay was conducted between October 2014 and November 2015 in Phnom Penh at the Tuol Sleng Genocide Museum, Documentation Center of Cambodia (DC-Cam), and Bophana Audiovisual Resource Center.

${ }^{2}$ Rithy Panh, The Missing Picture (Cambodia \& France: Catherine Dussart Productions (CDP), 2014), film.

${ }^{3}$ Andreas Huyssen, "Of Mice and Mimesis: Reading Siegelman with Adorno," New German Critique 81, Dialectic of Enlightenment (2000), 65-82.

${ }^{4}$ David Munro, Year Zero: The Silent Death of Cambodia (United Kingdom: Associated Television (ATV), 1979), 50'.
} 
South East Asian specialists, intellectuals and historians alongside journalists, like Jean Lacouture, celebrated what appeared to be an innovative revolution. Such was the case of controversial leftwing personalities like Noam Chomsky, Malcolm Caldwell, George Hildebrand, Gareth Porter and Per Olov Enquist, to name but a few. In contrast, however, alarming evidence of an ongoing mass murder reached Western circles based on leaks and refugees' testimonies, dating from the very seizing of power by the Khmer Rouge, the evacuation of Phnom Penh and the dramatic events at the French Embassy during the weeks that followed. Sidney Schanberg was the first to bring it to the public attention in The New York Times (May 9 1975), ${ }^{5}$ while Father François Ponchaud denounced the massacre in a series of articles later transformed into his January 1977 book, Cambodia: Year Zero. ${ }^{6}$ But whatever corroborated the content and sources of the news coming out of Cambodia, none of these rumors and witnesses' voices were substantiated through visual sources, that were lacking until January 1979. The scarcity of images fueled the imagination, which led to George Hildebrand and Gareth Porter reproaching Schanberg for having paved the way to associate in the psyche of the American public the evacuation of Phnom Penh with the infamous "death marches" of European Jews, at a period of heightened sensitivity towards Israel. ${ }^{7}$ There were no images, or hardly any, and those which existed served to both enlighten and mislead us.

In March 1978, during a peak moment of the internal purges within the Communist Party of Kampuchea, a television crew from Televizija Beograd (Yugoslavia) was invited to film in the country for two weeks, and took advantage of its non-alignment with the USSR or China. Cameraman Nikola Vitorovic captured the deserted streets of Phnom Penh, as well as of labor camps and other scenarios prepared by their hosts to endorse the economic, social and political achievements of the revolution. When the footage was released in the West on March 21, 1978, it paradoxically raised widespread suspicion, if not downright rejection of the Khmer Rouge. ${ }^{8}$ Although the images were per se ambiguous, the human emptiness they portrayed hinted at a nation going back towards an agrarian past, transforming its major urban areas into ghost towns and converting the whole country into a concentration camp. Another guest during this official campaign to open Democratic Kampuchea to the outside world in the last months of the regime was the journalist Elizabeth Becker, from the Washington Post, who arrived accompanied by the photographer Richard Dudham and professor Malcolm Caldwell, an enthusiastic Khmer Rouge supporter who was murdered under mysterious circumstances the night following his private interview with Pol Pot on the eve of his departure. ${ }^{9}$ The photos taken depict them as tourists posing nonchalantly scarcely two weeks before the regime collapsed. ${ }^{10}$ What struck Becker, who could draw on her past experience of the

\footnotetext{
${ }^{5}$ Sidney Schanberg, “Cambodia Reds Are Uprooting Millions as They Impose a 'Peasant Revolution,'” The New York Times, May 9, 1979, 1 and 15. Written from Bangkok.

${ }^{6}$ Beyond this "wall of silence", Ponchaud's sources were hundreds of witnesses' accounts, the Radio Phnom Penh broadcasts, and the party organ, the Voice of Democratic Kampuchea (Francois Ponchaud, Cambodia Year Zero, (New York: Reinhardt and Winston, 1978) [French original from 1977], ix).

${ }^{7}$ George Hildebrand and Gareth Porter, Cambodia. Starvation and Revolution (New York and London: Monthly Review Press, 1976), 73. These two authors, who were sympathetic to the Khmer Rouge, published in their book two photographs dated after April 17, Ibid., 80, 90.

${ }^{8}$ This footage under the title of Kampučija' 78 was inserted into a French television program entitled Question de Temps, used as a basis for discussion and repeatedly re-appropriated. Nikola Vitorovic, "Kampučija' 78," filmed 1978, YouTube video, posted [June 2011], accessed November 19, 2017, https://www.youtube.com/watch?v=BjpHZClAGbU. By the time this piece was released, the reality of mass murder in Democratic Kampuchea had already ceased to be a mystery. John, "Cambodian Ghost City in 1978- Phnom Penh Emptied of 2 Million People," Wonderland 1981 (blog), October 25, 2012, https://wonderland1981.wordpress.com/2012/10/25/cambodian-ghost-city-in-1978-phnom-penhemptied-of-2-million-people/. A meticulous description and analysis of the context in which this 'charm offensive' by the Pol Pot regime operated can be found in Stéphanie Gauthier, Images of Khmer Rouges Atrocities. Visualizing the crimes of the Pol Pot's regime in transnational contexts of memory, 1975-2015 (Amsterdam: Wöhrmann, 2016), 47-53.

${ }^{9}$ Elizabeth Becker, When the War Was Over. The voices of Cambodia's Revolution and Its People (New York: Simon and Schuster, 1986), 406-436. Caldwell had ardently supported in 1975 the moral superiority of the Cambodian (and Vietnamese) revolution and elaborated a theory of "revolutionary violence" including his defense of the evacuation of Phnom Penh. See Malcolm Caldwell, "Revolutionary Violence in a People's War," Social Scientist, 3, no. 1 (1975), 43-52. Yet his strange silence during the trip, as Becker recounts it, suggest a more skeptical position in 1978 towards the regime.

${ }^{10}$ These photographs can be consulted at the Bophana Audiovisual Resource Center (Phnom Penh), Elizabeth Becker collection as record of the exhibition A Reporter's Dangerous Tour in Democratic Kampuchea (2012).
} 
country, was the disheartening absence of people much more than the conspicuous propaganda settings arranged for them by their hosts.

Nevertheless, if these small groups had been invited to counter the increasingly criminal reputation of the Pol Pot regime in the West, the Swedish Maoist leader Gunnar Bergström's walkabout in the summer of 1978 had a different significance, that of comradeship. As president of the Sweden-Kampuchea Friendship Association, Bergström was well disposed to certify the achievements of a revolution he had so enthusiastically celebrated. To furnish his conviction with an indisputable sign of veracity, he resorted to taking his own photographs. ${ }^{11}$ Yet, on examining them, some questions inevitably arise: did the visible evidence provide arguments for the political stance the author was already convinced of? Or, to put it retrospectively, were the images actually a witness to the exploitation, violence and suffering going on behind the scenes? While Becker never seems to have questioned her own photographs in regard to her rising mistrust of her hosts, Lacouture's repentance in 1977 for having supported the Khmer Rouge gave way to numerous media interviews, ${ }^{12}$ after 1979 resulted in trips to the Cambodian murder sites, and active condemnations, including the writing of several prefaces in memoirs and reports. Bergström's case is much more revealing. When he realized, as soon as the end of 1978, the criminal status of the regime he had supported, he suffered a devastating crisis of conscience and intoned a sincere mea culpa that many years afterwards brought him back to Cambodia. In 2008 and under the auspices of DC-Cam, the trip bore visual fruit with an exhibition at the Reyum Arts Gallery (November 2008) and the publication of his 1978 photos in the form of a catalogue-like book. He then proceeded to comment on the voids, absences and suspicious details he had been blind to thirty years before. However, beyond the unequivocal sincerity of his contrition, one might wonder to what extent the images taken in 1978 were as transparent as his new captions seem to suggest or, on the contrary, they were actually being interpreted in 2008 in the light of his damascene conversion. If the second hypothesis is correct, these photographs bolster documentary maker Errol Morris' claim that, as far as photography goes, "believing is seeing", that is to say, that photographs usually 'confirm' the observer's previous beliefs rather than lead him or her to discover something new. ${ }^{13}$

All of the above refers, of course, to observers from abroad, nonetheless, the regime itself also produced powerful iconography. Under the auspices of its Chinese advisors, the Pol Pot photographic and cinematographic propaganda services elaborated an arsenal of images intended for the education of party cadres and whenever possible to be screened in mobile projections to the entire population. These myth-like compositions of a rural utopia of peasants organized in communes, workers in factories or men and women eagerly building dams are, in film terminology, the reverse shot of the genocide, an engorgement designed to leave the atmosphere of violence offscreen, even though a close examination of the footage (which is perhaps more difficult to apply to still photographs) detects elusive gazes, over-orchestrated mass movements, and mechanical gestures that imply careful rehearsal.

Finally, if we turn our attention to the images invoked throughout more than thirty-five years to represent the crimes of Democratic Kampuchea, a substantial number of them correspond to the detention, torture and execution center code-named S-21. In fact, S-21 had the singularity of having been conceived by the security police for the repression of internal enemies. For this reason, the center was placed under the direct control of the Angkar (the Khmer word for the Organization) and its commandant received direct orders from the Ministry of Interior, Son Sen, later Nuon Chea, and even from "Brother Number One," that is, Pol Pot himself. Its discovery in the days that followed the fall of Phnom Penh provided the Vietnamese invaders with extremely

\footnotetext{
${ }^{11}$ Gunnar Bergström and Hedda Ekerwald, Living Hell. Democratic Kampuchea, August 1978 (Phnom Penh: Documentation Center of Cambodia, 2008).

${ }^{12}$ See the review of François Ponchaud's book by Jean Lacouture, "The Bloodiest revolution," The New York Review of Books, March 31, 1977, 42F. In this article he applies the famous expression "autogenocide" to characterize the Khmer Rouge murderous policy and affirms unequivocally: "François Ponchaud's book can be read only with shame by those of us who supported the Khmer Rouge cause." Besides other TV appearances, Lacouture would be filmed in Tuol Sleng and the killing fields of Choeung Ek in 1990 (Grâce et horreur. Retour de Jean Lacouture au Cambodge (Antenne 2).

${ }^{13}$ Errol Morris, Believing is Seeing. Observations on the Mysteries of Photography (New York: Penguin, 2011).
} 
important documentation, alongside macabre imagery lying in the courtyard and, in some cells, human bodies executed in extremis, shackled to beds, prisoners' rags, instruments of torture and thousands of mug shots of the detainees. Aware of the importance of the findings, the Vietnamese recorded every detail with their cameras and proceeded without delay to classify the files.

\section{The Imagery of Genocide}

Limiting our scope to the images used to represent the violence exerted against the enemies of the regime, whether we call it genocide or not, they could be classified into four categories according to their visual enunciation, that is, the relationship between the gaze which holds the images and their contents. ${ }^{14}$ The first category is made up of the perpetrator images produced by the Khmer Rouge's machinery of repression. Among these, the mug shots of the detainees captured during detention stand out, which set in motion an obligatory sequence of events for all detainees until their annihilation (anatomic measurement, interrogation, a written confession approved by the director, and denouncing the treacherous networks they allegedly belonged to), concluding inexorably with their execution. I label them perpetrator images on the grounds that they embody the executioners' gaze. This does not mean that they adopt the actual killer's point of view, but that of the apparatus of destruction. To that camera the victims reacted with an instantaneous facial expression at the precise moment when their blindfold was removed and they were dazzled by the bright light. ${ }^{15}$ It is no mere coincidence that Nic Dunlop called these snapshots "trial by camera."16

The second category consists of the liberator images, that is, the pictures and moving images recorded by the Vietnamese upon the discovery of S-21 with a view to denouncing the levels of atrocities and to producing evidence for a trial against the murderers.

The third category, made up of belated evidential-images, constitutes a less unified corpus, but refers to images produced by visitors and guests, such as foreign reporters, diplomatic delegations, news agencies and human rights organizations that filmed the crime scenes motivated by various objectives (news coverage, denunciation, personal record, sometimes with a touch of voyeurism...). Although it is difficult to precisely set the chronological limits of this production of images, its richest period preceded the official opening of the museum of genocidal crimes in 1980, but did not stop there.

The fourth and last category -creative imagery- is primarily represented by a series of canvases painted by the artist survivor Vann Nath from November 1979 onwards, when he was hired by the museum's administration to document the scenes occurred at S-21, which he did adopting a disturbing naïve style. ${ }^{17}$

As rich as all these categories of images may be as a visual aide to document the Cambodian genocide, all four are, to a greater or lesser degree, insufficient, ambiguous and contestable as evidence. With regard to the perpetrator images, they are by their very nature indiscernible from the gaze and purpose that originated them, constituting a mise en scene of the enemy-to-be-destroyed, even though some details we can perceive in the photos were unintentional, particularly capturing the prisoner's reaction. The liberator images have arguably the initial advantage of having been taken without preparation as the Vietnamese victors entered the city. Yet, a closer examination of the structure of the buildings and cells reveals that the photographs and films must have been the result of some preparation, including analysis of the role played by the rooms, offices, objects

\footnotetext{
${ }^{14}$ Vicente Sánchez-Biosca, "Perpetrator Images, Perpetrator Artifacts: The Nomad Archives of Tuol Sleng (S-21)," Cinema E Cie. International Film Studies Journal XV, no. 24 (2015), 103-116. These categories -we are bound to add-follow somehow a chronological order of manifestation.

${ }^{15}$ As far as the registration system goes, David Chandler, Voices from S-21. Terror and History in Pol Pot's Secret Prison (Los Angeles \& London: University of California Press, 1999); Michelle Q. Hamers, “Do Nothing, Sit Still, and Wait for My Orders. The Role of Photography in the Archive Practices, Historiography, and Memory of Democratic Kampuchea 1975-1979" (unpublished thesis, March 2011).

${ }^{16}$ Nic Dunlop, The Lost Executioner. A Journey into the Heart of the Killing Fields (New York: Walker Publishing Company, 2006), 148.

${ }^{17}$ Vann Nath, A Cambodian Prison Portrait. One Year in the Khmer Rouge's S21 (Bangkok: White Lotus, 1998). An analysis of this crucial painter's imagery, Vann Nath Tribute (Phnom Penh: Bophana Center, 2013). I deem this style disturbing on the grounds of the apparent discrepancy between the horrendous scenes of torture and crime depicted and the naïve use of color, drawing and perspective.
} 
and photos. In fact, all these aspects were exploited in the filming by the efficient use of cinematic devices (close-ups, camera movements, editing and montage). A priori, the belated evidence-images, although heterogeneous, seem freer from bias. However, in 1979-1980, the visitors to Tuol Sleng were not spontaneous crowds, but highly motivated individuals: some working for countries sympathetic to Vietnam, some inclined to accuse the Khmer Rouge for their crimes, and finally others committed to humanitarian tasks. Consciously or not, all of these photographed and filmed places had been carefully chosen and strategically set out by the museum's management. ${ }^{18}$ In this respect, we must remember that the Vietnamese colonel Mai Lam, the éminence grise of the Tuol Sleng Museum, had moved to Phnom Penh in January or February 1979 commissioned to gather evidence for a trial against Pol Pot and Ieng Sary that would be carried out in absentia in August 1979. To this end he worked in close collaboration with S-21 survivor Ung Pech. ${ }^{19}$ Their investigative work left an indelible trace, although apparently imperceptible, in the way visitors observed, photographed, and filmed the site. Finally, Vann Nath's paintings are reconstructions of some scenes he had personally experienced, along with others (in fact, the vast majority) that he had been told about by other victims while he was incarcerated in the workshop of S-21 between 1977 and the end of the regime..$^{20}$ No matter how illuminating these artistic pieces might be in order to grasp the events that had taken place in the prison by the time Vann Nath was working under the Vietnamese administration on the same crime scene, they are by no means first-person visual experiences, but an artistic recreation of what they depict.

\section{In the Wake of the Holocaust}

In perspective, taking into consideration the ambiguity of these four categories to represent the Cambodian genocide brings to mind an axiom that had been called upon in the exponentially growing bibliography of the Holocaust over many decades: the futility of attempting to represent the murderous acts or, in less emotive terms, the awareness that no image whatsoever could faithfully capture the events that occurred. In reality, this topic (which strictly speaking is valid for any human experience) adapts to the universe of images an influential concept that the early memories of the survivors of the Nazi extermination camps (Primo Levi, Elie Wiesel, Jean Améry, Charlotte Delbo, among others), had put forward after their return from them: the ineffable or, in narrative terms, the untellable nature of the experiences suffered. As Primo Levi described it in his seminal account If this is a man in conclusive terms: "[T]hen for the first time we became aware that our language lacks words to express this offense, the demolition of a man." ${ }^{21}$ And it is no surprise that Wiesel resorted to mystical language in key moments of his writings to address such extraordinary and catastrophic events.

Given the focus of this article, now is not the moment to delve into the massive literature on this subject. Nevertheless, we should not forget that, however persuasive these metaphoric expressions on the fragility of language may be, as time went on, written, oral or filmed testimonies delivered by less gifted authors have made this rhetorical figure commonplace. What is more, the acknowledgement of the insufficiency of language in turn echoes a more abstract philosophical question: the challenge posed by genocide to rational understanding. This question tormented prominent German intellectuals from various disciplines: the philosophers, Theodor W. Adorno

\footnotetext{
${ }^{18}$ Even though the museum did not open formally until 1980, its structure and narrative were highly advanced in the spring of 1979. In that period, official representatives and survivors regularly took select groups of visitors to the facilities.

${ }^{19}$ According to his interview with Peter Maguire, Mai Lam was first commissioned to gather evidence for the trial, then to collaborate on the museum the lay out. Peter Maguire, Facing Death in Cambodia (New York: Columbia University Press, 2005), 89; Tom Fawthrop and Helen Jarvis, Getting Away with Genocide?: Elusive Justice and the Khmer Rouge Tribunal (London \& Ann Arbor: Pluto Press, 2004), 41.

20 “The drawings, Vann Nath noted, consisted of three types: 'First, what I saw with my own eyes. Number two, [what] I only heard [about] but could imagine. 'And number three, [what] I heard from prisoners [with whom] I shared the [workshop] room'"' (Alex Hinton, Man or Monster? The Trial of a Khmer Rouge Torturer (Durham: Duke University Press, 2016), 182, quoting Vann Nath's testimony on Day 35 at the hearings).

${ }^{21}$ Primo Levi, Survival in Auschwitz. The Nazi Assault on Humanity (New York, Oxford, Singapore, Toronto, and Sydney: Macmillan, 1986 [1948]), 26.
} 
and Max Horkheimer, the mass sociology scholar, Siegfried Kracauer, the political scientist, Hannah Arendt, the psychoanalyst, Bruno Bettelheim, Karl Jaspers in the field of ethics and so on. The unresolved question could be formulated as follows: why did the principle of reason that came into being during the Enlightenment not prevent mass murder? Briefly, the unconceivable, the untellable and the non-representable form a triptych underscoring the difficulties that a human mind faces when it attempts to comprehend, recount and represent the Holocaust. Then, by natural genealogy, all three stumbling blocks have been adapted by scholars to address later genocides. From this perspective, rather than literally, this triptych should be taken as a warning against attempts to achieve absolute accuracy.

In the light of the above, it comes as no surprise that numerous authors have claimed that the Cambodian genocide is untellable or non-representable as illustrated by the following examples. The French photographer Bernard Plossu used such terms in his preface to Dominique Mérigard's pictures of Tuol Sleng. ${ }^{22}$ The archive specialist Michelle Caswell introduces the term in the very title of her book devoted to documenting S-21 prisoners' mug shots and their migration from art galleries to the criminal court: Archiving the Unspeakable. ${ }^{23}$ Soko Phay-Vakalis brings together the non-representable with the ghost images in her account of the artists whose work originates in the destruction of the Cambodian visual heritage. ${ }^{24}$ The same can be said for Viet Le when he approached Tuol Sleng from the angle of cultural trauma and, last but not least, the British scholar Ashley Thompson appeals to such terms when commenting on a meaningful artistic manifestation entitled symptomatically The Legacy of Absence. ${ }^{25}$

Assuredly, the examples could continue, but in general terms a certain ambiguity remains regarding the exact meaning of "untellable" or "un-representable". I would argue that the nonrepresentable can designate three distinct issues: firstly, it can draw our attention to the actual lack of images portraying mass violence, as the criminal acts occurred beyond the scope of the cameras; secondly, it can assess our awareness of the inadequacy of the surviving images to render the enormity of the crimes committed; and thirdly, it may denounce the obscenity of using any kind of images to illustrate mass crimes and genocide, as far as human affliction is involved. In fact, a famous controversy followed in the wake of Didi-Huberman's essay "Images in spite of all," which analyzed four photographs taken by the Sonderkommando from Birkenau in the summer of 1944 in extreme conditions of risk and taken out of the camp. While Didi-Huberman claimed that, in spite of their limited information (or perhaps thanks to that) these photographs, as remnants, merited close analysis, the filmmaker and author of Shoah, Claude Lanzmann, rejected their value, and furthermore categorically condemned any use of archival images on the murder of the European Jews by artists and historians on the grounds that none of them represent the annihilation in itself. Instead, he appealed for survivors' accounts. ${ }^{26}$

\section{Searching In Between}

I would like to beg the reader's indulgence for a moment to make a necessary brief detour, to provide the framework in which the Cambodian genocide inherited the notion of the non-representable. In following the interdictions, taboos, and suspicions derived from Holocaust studies, the images of the crimes committed by the Khmer Rouge are thin on ground. This scarcity constitutes the implicit cornerstone on which Rithy Panh based his research for The Missing Picture that points to the heart of what an image can do, not only in the sphere of representation, but also as an instrument of

\footnotetext{
${ }^{22}$ Bernard Plossu, "Dire l'indicible", Dominique Mérigard, Témoin S-21. Face au Génocide des Cambodgiens (Manosque, le bec en l'air, 2008), n.p.

${ }^{23}$ Michelle Caswell, Archiving the Unspeakable. Silence, Memory, and the Photographic Record in Cambodia (Madison: University of Wisconsin Press, 2014).

${ }^{24}$ Soko Phay, "Missing Images of Genocide and Creation in Cambodia," Journal of Literature and Trauma Studies 4, no. 1-2 (2015), 88 and 97.

${ }^{25}$ Lê Việt, "What Remains: Returns, Representation, and Traumatic Memory in S-21: The Khmer Rouge Killing Machine and Refugee," American Quarterly 66, no. 2, (2014), 301-332; Ashley Thompson, "Forgetting to Remember, Again: On Curatorial Practice and Cambodian Art in the Wake of Genocide," Diacritics 41, no. 2 (2013), 82-109.

${ }^{26}$ Georges Didi-Huberman, Images in spite of all (Chicago: Chicago University Press, 2008).
} 
healing. ${ }^{27}$ Inasmuch as Panh's previous documentaries had made extensive use of a variety of images genres (archival, reenacted, re-appropriated...), his current claim that the key image to comprehending the genocide is missing raises major issues. In 1989, Panh directed Site 2, filming a non-lieu de mémoire (non-site of memory), the biggest refugee camp on the Thai border in the same area (after fleeing from the Khmer Rouge he had actually stayed in a refugee camp called Mai Rut). In 1996, he reversed the mug shot of a young girl to redeem her and transform her into the heroine of his film Bophana: A Cambodian Tragedy. ${ }^{28}$ In 2000, the filmmaker followed a fiberglass installation through the country by Alcatel to unearth a past that was concealed below the landscape, such as bones and landmines. ${ }^{29}$ Convinced that the torture and execution center S.21 was haunted by the spirits of the victims, he managed to convince ordinary executioners and two survivors to reenact their gestures, words, and deeds of former times at the same spot. ${ }^{30}$ Then during the first trial by the Extraordinary Chambers in the Courts of Cambodia (ECCC) against Kaink Guek Eav (alias Duch) he approached and engaged in a long and soul-consuming interview with the master executioner. ${ }^{31}$ It goes without saying that in 2013 the primal images we have categorized above had been extensively used, combined, and changed from framework to framework (propaganda, art, human rights discourse, transitional justice, and so forth).

But more precisely, The Missing Picture is chronologically located in an advanced phase of he searches and inquiries. Moreover, it plays a therapeutic role that can only be grasped in the light of his encounters with the executioner Duch: 300 hours of interviews with the man who had been in charge of the most relentless apparatus of destruction of Democratic Kampuchea. During those clashes, Duch's cold behavior and mastery in face-to-face confrontations (as the expert in interrogation he was for years), destabilized the filmmaker to the extreme of bringing on a crisis of anxiety. In fact, after 2009 the former victim began an intense period of self-examination that bore two precious fruits: the book co-written with Christophe Bataille, The Elimination (published in France in 2011), and the intimate memory work represented by The Missing Picture, whose narrative was written also in collaboration with Bataille. This novelist, ever since a close collaborator of Panh, remembers the dire process in this way: "I only understood later and little by little that he was in mortal danger, since Duch had brought him into deadly areas. After the ordeal of filming Duch, Master of the Forges of Hell, the project of this book [The Elimination] was without a doubt a means of rebuilding his identity." ${ }^{32}$ The Elimination juxtaposes Panh's childhood recollections with a diary of encounters with Duch and functions like an act of exorcism. ${ }^{33}$

When Rithy Panh resolves to make The Missing Picture an intimate recovery of his traumatic childhood, the echoes and reverberations of all the images evoked are not only latent, but experienced as somewhat deceptive. Likewise, no matter how successful his attempt to retrieve, restore, and make public the Cambodian visual heritage through his and Ieu Pannakar's 2006-born institution, the Bophana Audiovisual Resource Center, these images did not fulfill his ultimate need to express suffering. Let us then put the enigma straightforwardly: what is the missing picture in The Missing Picture?

To begin with, the expression "missing picture" begs an automatic response which consists of seeking the genuine one in the archives. The film voiceover soon prompts a series of hypotheses: is the missing picture the heartbreaking one showing a Khmer Rouge execution? Is it perhaps the

\footnotetext{
${ }^{27}$ Panh, The Missing Picture.

${ }^{28}$ Rithy Panh, Bophana: A Cambodian Tragedy (France \& Cambodia: Catherine Dussart Productions (CDP), 1996), 59'.

${ }^{29}$ Rithy Panh, The Land of Wandering Souls (Cambodia \& France: INA, 2000), 100'.

${ }^{30}$ Rithy Panh, S.21: the Khmer Rouge Killing Machine (Cambodia \& France: Institut national de l'audiovisuel, 2003), 101'.

${ }^{31}$ Rithy Panh, Duch: Master of the Forges of Hell (Cambodia \& France: Catherine Dussart Productions (CDP), 2011), 103'; On Rithy Panh's approach to Cambodian genocide and ending in The Missing Picture, see Deirdre Boyle, "Finding the Missing Picture: the Films of Rithy Panh," Cineaste no. 28 (2014), 28-32.

${ }^{32}$ Christopher Bataille to the journalist François Ekchajzer ("Rithy Panh vit dans la mort, c'est un rescapé, Christophe Bataille écrivain," Télérama, October 9, 2013, accessed November 17, 2017, http://www.telerama.fr/television/rithypan-vit-dans-la-mort-c-est-un-rescape-christophe-bataille-ecrivain,103199.php). Author's translation.

${ }^{33}$ Jonathan Romney mentions the function of "therapeutic exercise" in his critique published in Film Comment, Jonathan Romney, "Film of the Week: The Missing Picture," Film Comment, March 20, 2014, accessed October 29, 2017, https:// www.filmcomment.com/blog/film-of-the-week-the-missing-picture.
} 
unattainable metaphorical image of a childhood in the warm and cozy family house of Phnom Penh in the late-sixties; an image that vanished rapidly into thin air in the wake of the April-1975 evacuation? Or could this picture be the blurred, composite image of hunger, humiliation and death which shocked an unprepared adolescent to live in the surreal atmosphere of a forced labor camp? Regardless of the answer and however haunting and compelling the effect of this traumatic imagery, my claim is that the temptation to identify the missing picture is definitely misleading, insofar as it distracts us from what I believe is the real issue, namely: determining the mental point of view from which any image proves to be inconsistent, deceptive, and ultimately inadequate. Once ascribed to the perspective of he who recounts his memories, the missing picture reveals itself as a conceit, a pretext to initiate a desperate and metaphorical search through an intricate web of images of diverse status animated by different intentions, all of which torment the subject or precipitate him towards melancholia. While some are incomplete and untrustworthy, others become in turn nightmarish. In the end, retelling the author's memories is but an attempt to find his way through the pictures that made up a life ripped apart. In this sense, the viewer's initial impulse is a formal and psychological struggle to give form, meaning, and order to a fragmented and chaotic iconography. Hence, the best way to discover the missing picture appears to be the immersion in a jungle of other images related to this absence, either by association, or by opposition.

In fact, the title of the film echoes the phrase "the missing link," which applied to an image implies that a missing picture interrupts the chain of discourse, casts doubt on the consistency of the storytelling, and provokes anxiety. A rupture of this kind suggests that something our grasp of reality is incomplete and, in consequence, so is the transmission of memory. This inexorably incites the viewer to appeal to new images, since those referred to in the film go beyond the physical plane, and include inner, spectral, and traumatic images. It would be no overstatement to conclude that the major achievement of the film lies precisely in revealing the social catastrophe that accompanies the narrator's dismembered biography. In a nutshell, an image is not missing because it cannot be replaced by others (many images could eventually come to the rescue); but because it is strange and unrecognizable to the subject who strives to allocate it in his biography. This attention focused on the particular film continuum demands both a formal and semantic analysis, including frame composition, editing, narrative structure, and articulation between voiceover and the visual continuity. My contention in what follows is to point out how the filmmaker enriches the four categories of the aforementioned images, first, combining some of them in an innovative way, second, developing other types to apprehend the subjective aspects that are out of the reach of others' visual output. And this keeping in mind the new and varied frameworks in which the images of the Cambodian genocide have been incorporated.

\section{Material Memory Come Life}

The film commences among rusty celluloid film reels abandoned in the storeroom of a Cambodian film archive. This material is almost undecipherable, in a state of neglect; even though the nitrates are within our physical reach, the chemical support is so deteriorated that it seems nothing but a pile of coffins of missing people -like a metaphor for the country itself. This history recorded in cinematic form probably goes back to the ancien régime of Sihanouk or even earlier to the French colonial period, although another part may include footage from Democratic Kampuchea (1975-1978). Suddenly, over these apparently dead artifacts a hand scrolls down one of the reels, showing us the vividly colored and graceful figure of an Aspara dancer. Her beauty is enhanced greatly through the subtle movements she makes. It is no accident that this excerpt has been extracted from the film Apsara, directed in 1966 by prince Norodom Sihanouk and starring his own daughter, the princess Bopha Devi. ${ }^{34}$ Perhaps in recovering this scene Rithy Panh wished to recall the cultural milieu of his childhood as magic. In any case, the appearance of this figure brings to light all the mysteries which surround an image: its premature demise, its resurrection before a human gaze, its ultimate condition as artifact, its role in the traditional folklore and mythology, and its summoning up of the beauty of art. The use of slow motion gives a touch of estrangement to the footage, as if it were an epiphany from another world which had ceased to exist.

${ }^{34}$ Norodom Sihanouk, dir., Apsara (Cambodia: Khemara Pictures, 1966), 150'. 


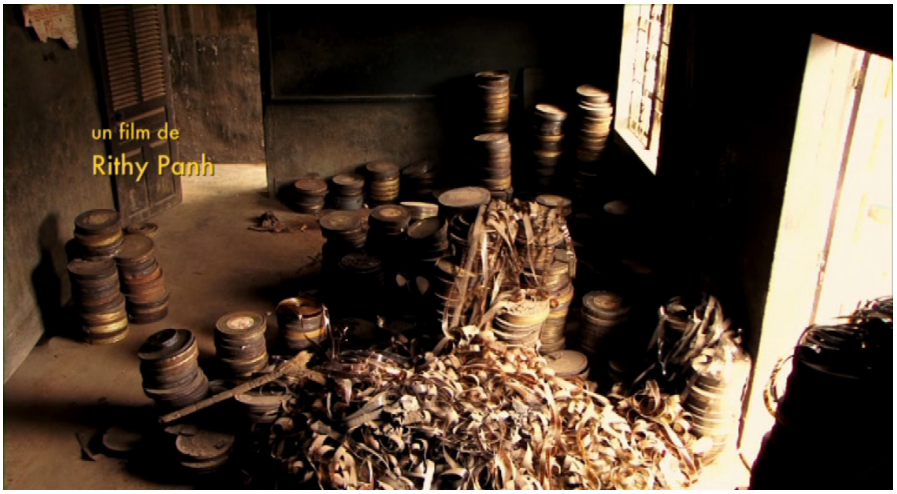

Figure 1.

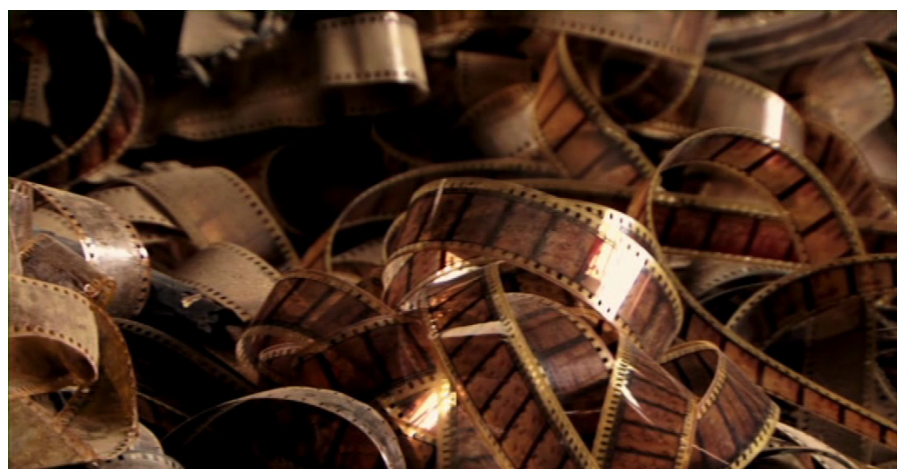

Figure 2.

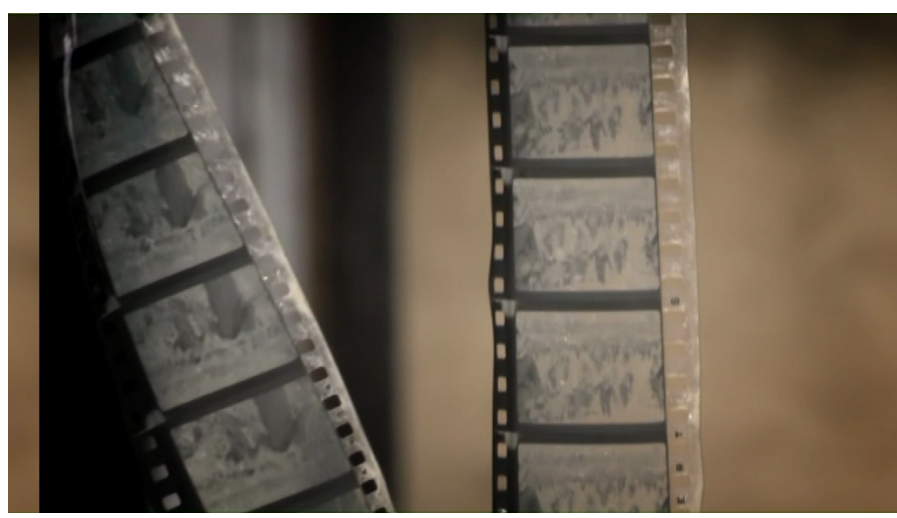

Figure 3.

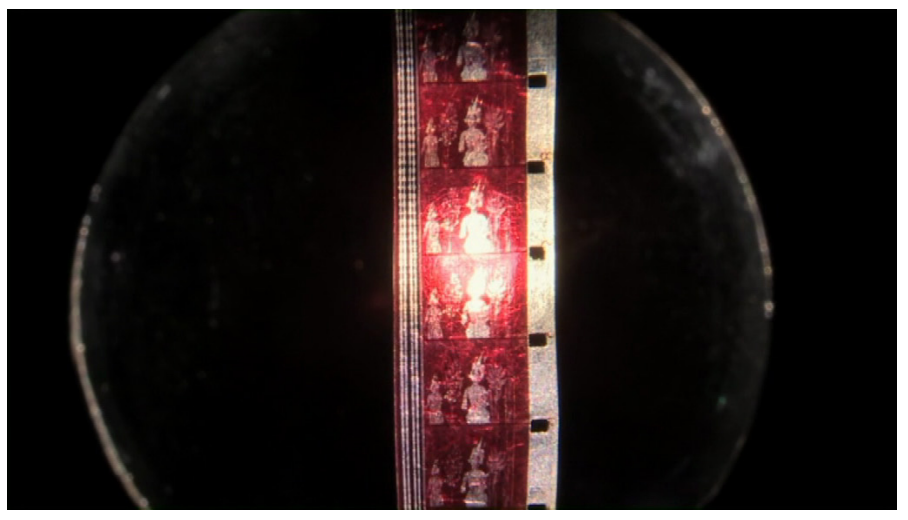

Figure 4. 


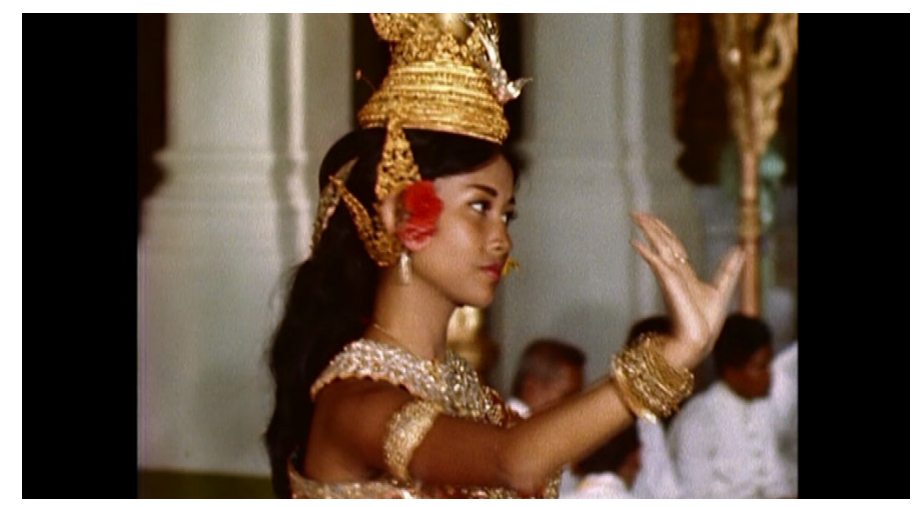

Figure 5 .

This association between vivid images and material relics appears at various moments during the film: Panh's eyes meet, as if hypnotized, the fragments of celluloid, which pass through his hands, before the shadows come to life. ${ }^{35}$ Then these are followed by a shot of seawater crashing into the camera lens, as if the subject of the gaze (and the viewer) were submerged in the bluegreen waters, deprived of perspective, unable to reach the surface and about to be engulfed. The connotations of these shots are fairly ambiguous per se, but in his interviews Panh has repeatedly referred to them as an expression of anxiety, an explosion of the senses, which is both blinding and suffocating. ${ }^{36}$ Whatever one's interpretation, these shots invert those that have preceded them: the images they contain are not under the thrall of the medium, and appear simultaneously as both liberating and threatening. What is more, the light pours onto the images, dazzling the viewer as if the dispositif, which caught the earlier shots, had dissolved and the eye was assaulted by a mass of water and light. It is then that the voice of the narrator begins his confession (through the voice of the actor Randal Douc) revisiting his childhood-in-images at the age of fifty, ${ }^{37}$ the experiences accumulated in life as a succession of losses. This same shot will reappear on four new occasions throughout the film, like a rhyme, positioned at strategic moments and at the closing of the film.

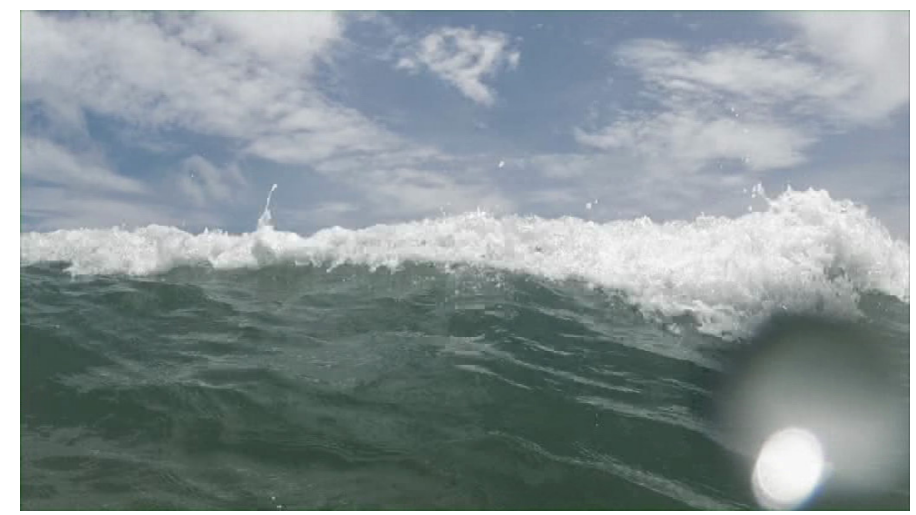

Figure 6.

${ }^{35}$ Rithy Panh's intimate account entitled The Elimination is defined as an excavation of the past by Y-Dang Troeung and Madeleine Thien, "To the Intellectuals of the West": Rithy Panh's The Elimination and Genealogies of the Cambodian Genocide," Topias 35 (2016), 57. That could be understood as an archaeological work through successive layers of images.

${ }^{36}$ Nick Bradshaw, "Memories of Murder: Rithy Panh on The Missing Picture," Sight \& Sound, June 5, 2017, accessed November 18, 2017, http://www.bfi.org.uk/news-opinion/sight-sound-magazine/interviews/memories-murderrithy-panh-missing-picture. Likewise, Lisa Duffaud, "Rithy Panh: L'image manquante, 2013 -CR de film de lecture," Indomémoires, April 3, 2015, accessed November 19, 2017, https://indomemoires.hypotheses.org/17375.

${ }^{37}$ It seems like a reference, mutatis mutandis, Dante Alighieri's Divine Comedy [1472], "nel mezzo del camin di nostra vita." For Dante it was at 30. 


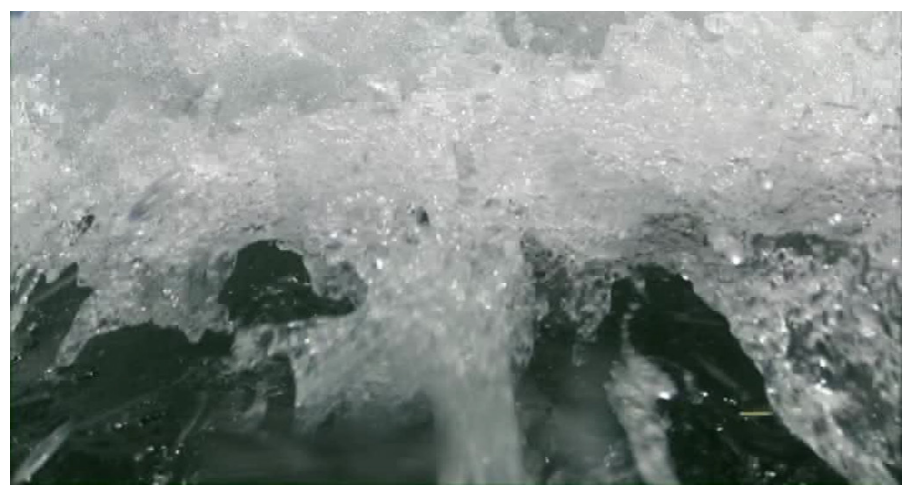

Figure 7.

Rithy Panh goes further in his search for images: he creates them, in the hope that they may capture the confusing experience he imagines is beyond representation. The first scene is what we might call the creation of man and constitutes the most original resource of the film: some small clay figurines designed by the artist Sarith Mang. "With earth and water, with the dead and rice fields, with living hands, we can build a man. It doesn't take much, you just have to wish for it." ${ }^{\prime \prime 8}$ The artist's hands sculpt the clay to obtain the first figurine before breathing life into it. One could describe it as a mixture of a childish toy making and the divine act that brought to life the primal Adam; perhaps also, the spirit that lives in the matter -the clay- as believed in Buddhism. Then the form, the color: the elegant but sober suit with white shirt and black tie. It is a simple but mysterious act: once the figure is complete, it is brought to life. It is a man, his Father.

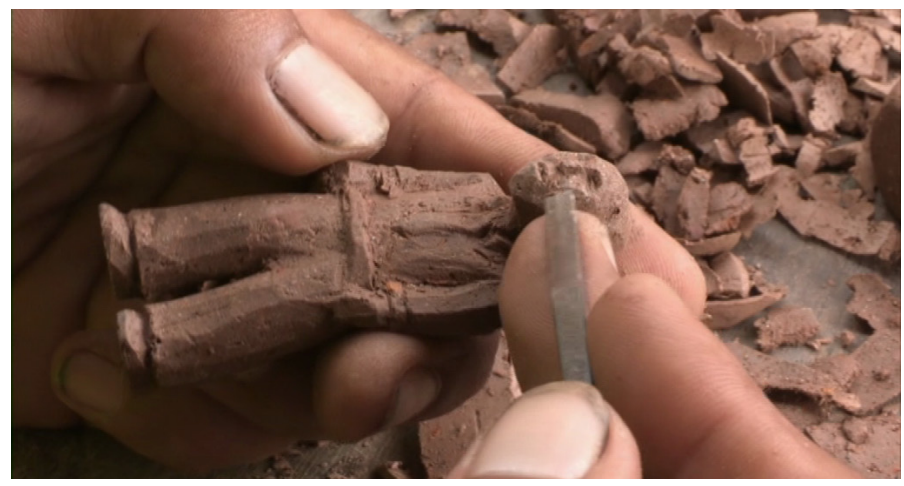

Figure 8.

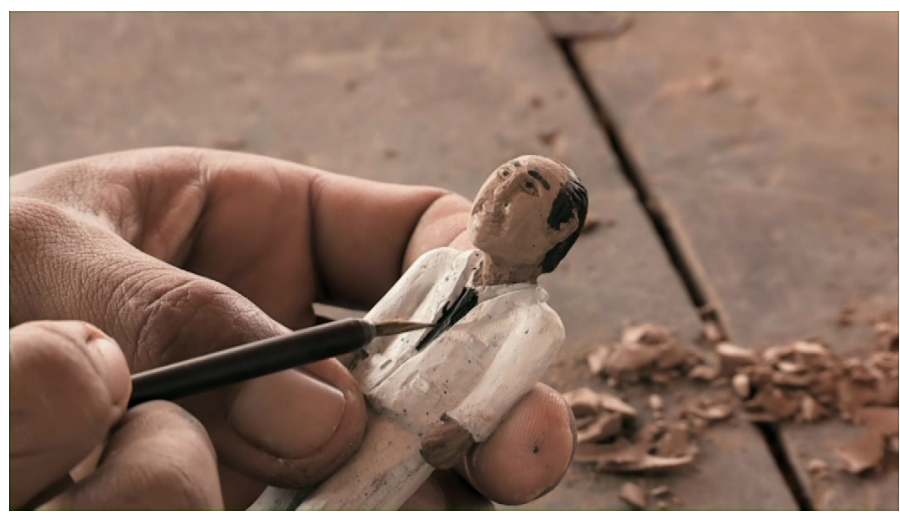

Figure 9.

\footnotetext{
${ }^{38}$ Rithy Panh and Christophe Bataille, L'image manquante (Paris: Bernard Grasset, 2013), 10.
} 
All things considered, in this act of creation, Rithy Panh offers the viewer an inverted sequence of the tragedy he is about to recount: the father whose life was taken away by the Khmer Rouge is brought back by the art of his son, who wishes to embrace him as soon as he returns from the abyss. It is a figurine touched by grace. From its inclusion in the set design, scenes of family life from Phnom Penh during the late sixties unfurl before the viewer in a colorful and festive atmosphere. These were filmed with a scale model before a $2 \times 2$-meter backdrop, ${ }^{39}$ and at night, so as to preserve the homogeneity of the artificial light which intimately bathed the scenes. It is a kind of all-enclosing atmosphere which brings to the present the olfactory memory of the city as remembered by the filmmaker: a stronghold of memory anchored in places long gone; the totally disfigured family home abandoned, turned later into a Karaoke bar and then a brothel. These sets combine warmth with a Brechtian distancing effect, which emanates from the stillness of the clay figurines, whose impassive expressions clash with the touching narrative plots. ${ }^{40}$ In a nutshell, the spectator is offered a small childlike set that stands for a period of time wiped from the pages of history. These sets will accompany the film throughout, but other images will soon abruptly tear this atmosphere apart. A sudden collage of archival footage changes the emotional tone.

The homely setting (reading, children playing, listening to music, father telling stories, the smell of fruit, school assignments, and so forth) is abruptly interrupted by an archive image, which, preceded by the sound of a helicopter, announces the fatal intrusion of the civil war, its consequences in human suffering, tearing-apart beauty: "Then the war came. Bombing came closer in the 70s. I remember the first casualties, our fear, my child's sadness. There are so many images in the world, which play on a loop. Images that we think we possess because we have seen them." ${ }^{41}$

These images stand for the 1970-Lon Nol military coup and the five-year civil war that ensued until on April 17, 1975 when the revolutionary troops marched into the city. Many of these archival shots had already been used by Rithy Panh in earlier films, as if he was trying to build a canon, that is, to associate a few moving images to key events of Cambodian history in the audience's mind. Rithy Panh states: "Sometimes I repeat the same archive film over many films. We have [access] the whole archive but I prefer to repeat the same images, because I want people to watch the same images each time." 42 In spite of this persistence, the use of slow-motion in these film shots make them seem unreal, threatening and even filled with foreboding.

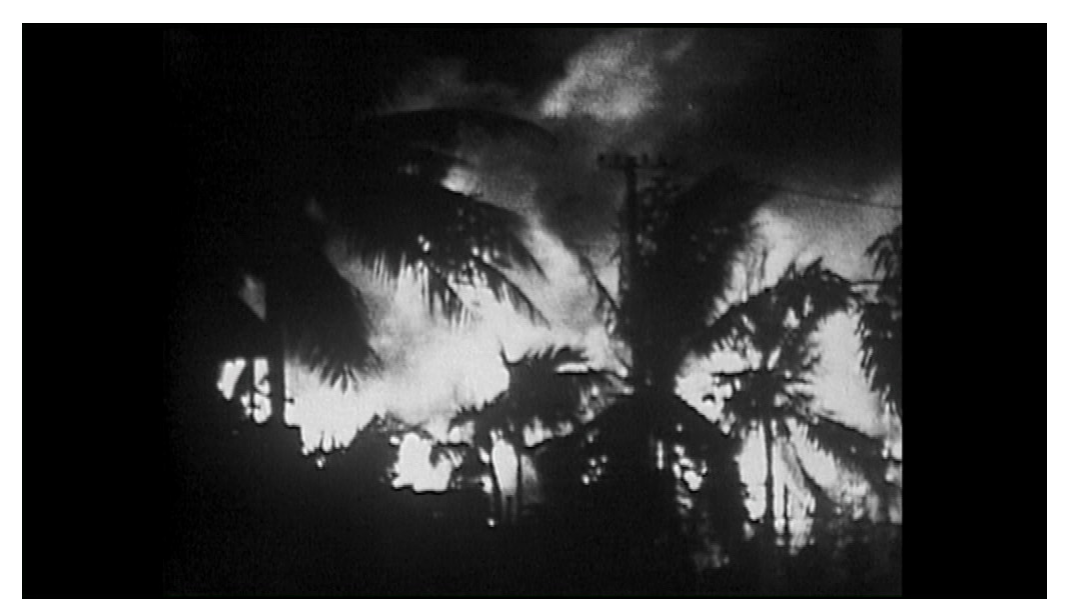

Figure 10.

\footnotetext{
${ }^{39}$ The setting is shown at a small scale as the final credits scroll down.

${ }^{40}$ Manohla Dargis, “Returning, in His Own Way, to the Killing Fields. 'The Missing Picture,' Rithy Panh's Look at 1970s Cambodia," New York Times, March 18, 2014, C6.

${ }^{41}$ Ibid., 11-12.

${ }^{42}$ Bradshaw, Memories of Murder.
} 


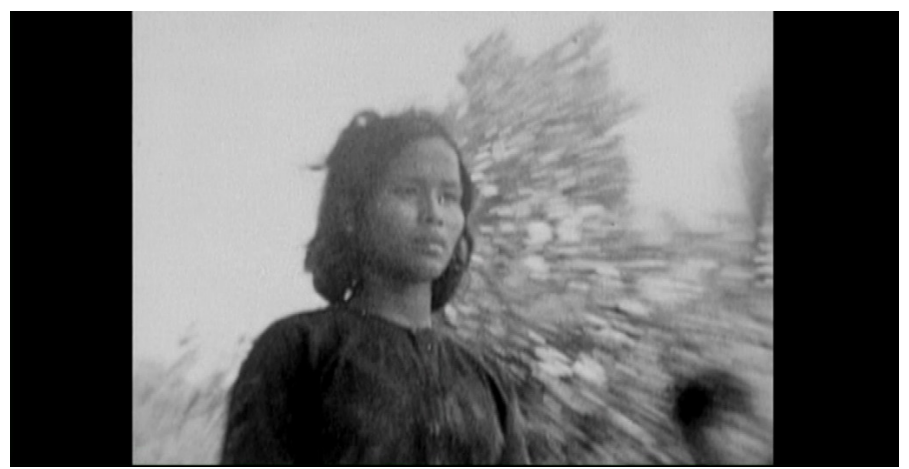

Figure 11.

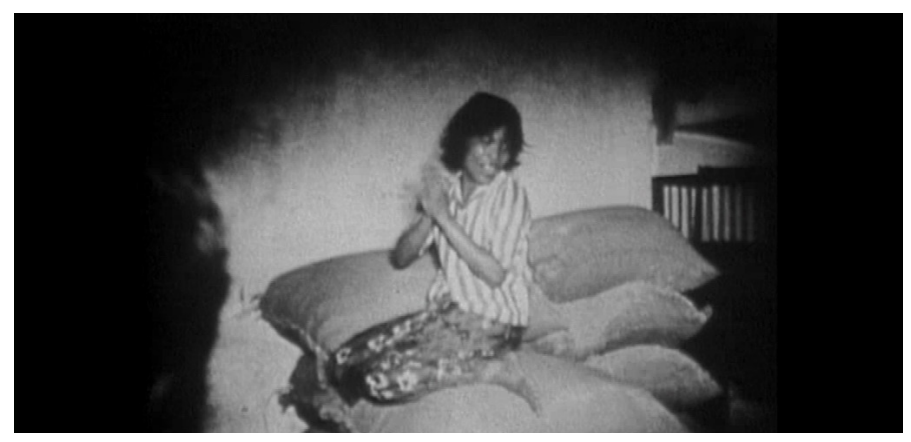

Figure 12.

All in all, throughout the film, the types of images used are extremely heterogeneous: some are collected from the news, others - the majority - come from scenes of the ongoing revolution set up by the Khmer Rouge to exhibit the disciplined masses (compulsive fists raised, never-ending acclamations, model schools and farms) in an ecstatic propaganda effort. These official films are shown in The Missing Picture through a filter, which mediates their interpretation: projecting a clay figurine onto the backdrop footage. In so doing, the images manufactured by the Khmer Rouge are re-appropriated by a point of view that makes the scene unrealistic. Yet on closer examination, the strategies used in these image-collages are very different from each other, as revealed by the still which are shown: the first shows the severity of a Khmer Rouge guard figurine displayed in the archival footage associated by repetition with the fall of Phnom Penh in April 1975; another inscribes over a propaganda film, depicting collective work in an immense reservoir, the figurine of the anonymous cameraman who might have shot this spectacular scene: a third shot focuses attention on the horror this same backdrop causes the figurine representing Rithy Panh himself, with his colorful shirt.

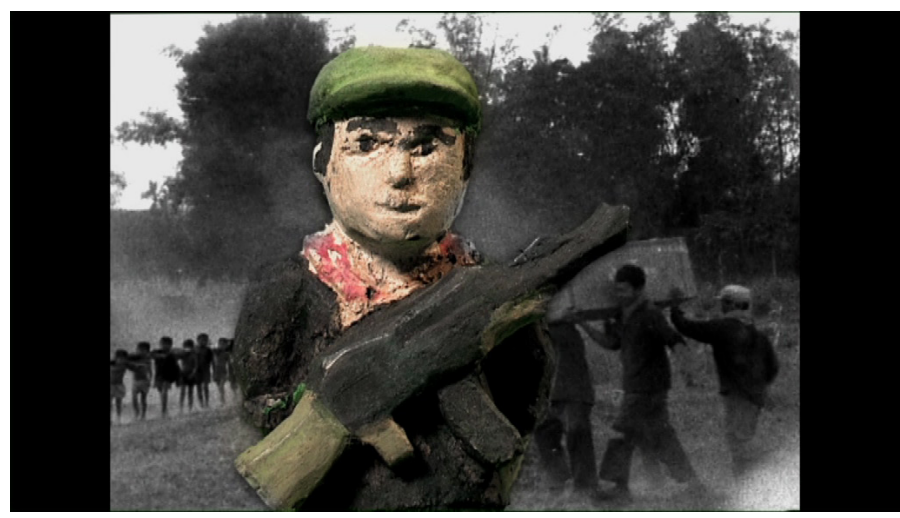

Figure 13. 


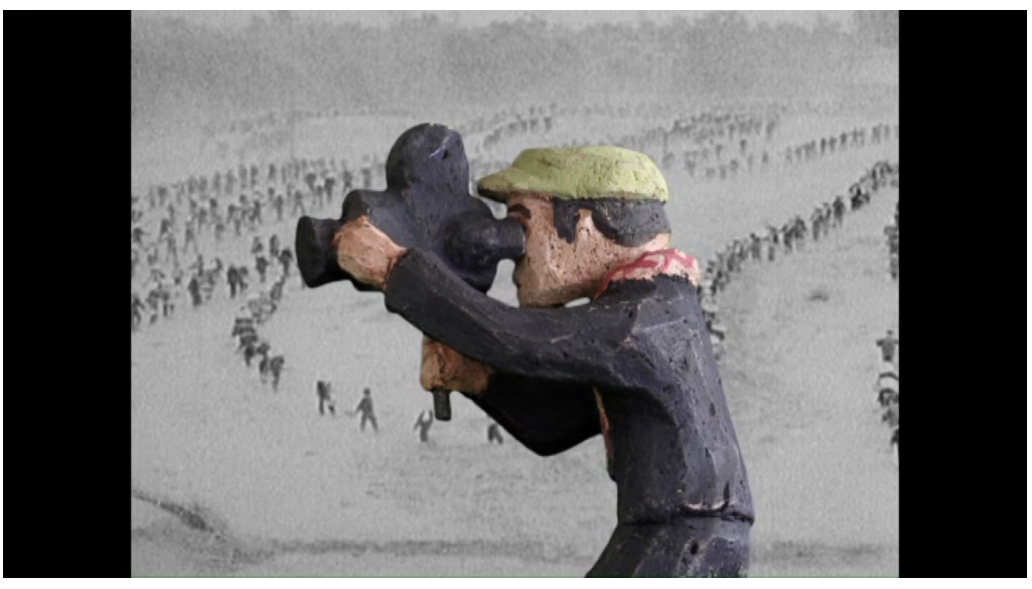

Figure 14.

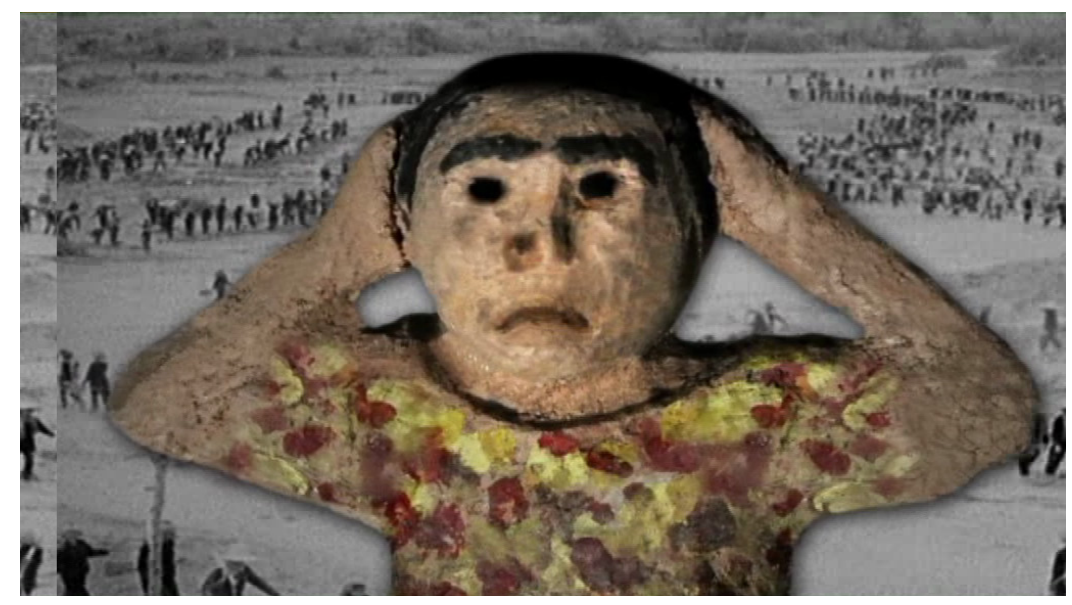

Figure 15.

A more in-depth analysis becomes necessary to address the way the images are selected, composed, assembled and edited in the continuum of an entire scene. In the pages that follow I will proceed to develop a more precise appraisal of three sequences representing three traumatic experiences that defy the imagination and bring to mind the four primal categories of images and their possible combinations. After all, the most demanding responsibility for a man of images (such is a filmmaker) consists of giving form to what resists being represented. This is, in short, the challenge of The Missing Picture. To achieve that goal, the author is constrained to mobilizing the cinematic resources of ellipsis, off-screen allusions, condensation and montage. The issue dwells on how all these devices contribute to better apprehending the void left by a missing picture. The scenes in question recount first, the death of the father, which burdens the son with undecipherable and contradictory sentiments of reproach and guilt; the second, the agony of a girl (actually his cousin), and third, the compulsive burying of victims performed by the young Panh. Even if all three sequences face the same difficulties in attempting to crystallize the meaning in a visual form, they materialize their response through distinctive forms.

\section{Death Scenes: Two Generations}

The father whose creation was referred to in the opening scene deteriorates physically and spiritually after months of hunger, forced labor, and humiliation. An educated man, trained as a teacher, he could not be considered by the Khmer Rouge as anything other than a corrupt example of what they called "new people", the middle-class urbanite by-product of capitalism for whom re-education was hardly conceivable. Not surprisingly, his deportation and the moral 
devastation had a diminishing effect on his spirits and, in an ultimate gesture of dignity, he made the decision not to feed on the food meant for animals and let himself die. Something not easy to grasp by his son Rithy, who fails to understand why his father abandons his whole family to its destiny. ${ }^{43}$

To give a decent burial to the dead man was unthinkable in such an ideological context where human life was worthless. Neither was the mourning permitted: "The Khmer Rouge -remembers Panh in an interview- made mourning impossible. The bodies were treated as objects: the corpses were treated badly. When one kills people in mass, there are no longer rites, no funerals. The identities of individuals are effaced. I try to re-construct these people. Give each a name." ${ }^{44}$ The enemies of the Angkar perished (of hunger, exhaustion or execution) without rights, their bodies were never handed over to their families, and no ceremony was ever given in their memory. Rithy's mother, instead, offered her stunned orphan a story narrating to him how according to tradition the teacher was given a sending off by his colleagues. A virtual tale, as it never happened, but this fiction lodged in the young man's mind more solidly than an actual event would ever have done. The mother's words thus exerted a healing effect, as they redeemed the inhuman reality through a performative act. This "enterrement de mots" (burial with words), as Rithy Panh calls it, soon turned into interior images to be kept as a treasure. At that point, the arduous task for the filmmaker lies in inventing a visual form for this perennial tale.

In his mise en scene, Rithy Panh reconstructs the sequence of agony with the austerity imposed by his figurines and setting. Once death comes, a group of statuettes representing the gravediggers depart in the midst of the night carrying the father's dead body into the forest. All of a sudden, the figures dissolve to leave a naked landscape before our eyes. The following shot is a ghostly image, deliberately out of focus, in which slender figures march in a funeral procession; then, as the focus sharpens, the figures reappear dressed in white and performing a ceremony that drastically inverts the humanity-erasing black pajamas that were compulsory under the Khmer Rouge. No one has ever seen this image, since it never existed. It is a post facto reconstruction invented by the filmmaker in order to give shape to an oral tale, and through it preserve at least his memory. Instead of a missing picture, Panh desperately finds an imagined image to bear the wound of a fatal loss.

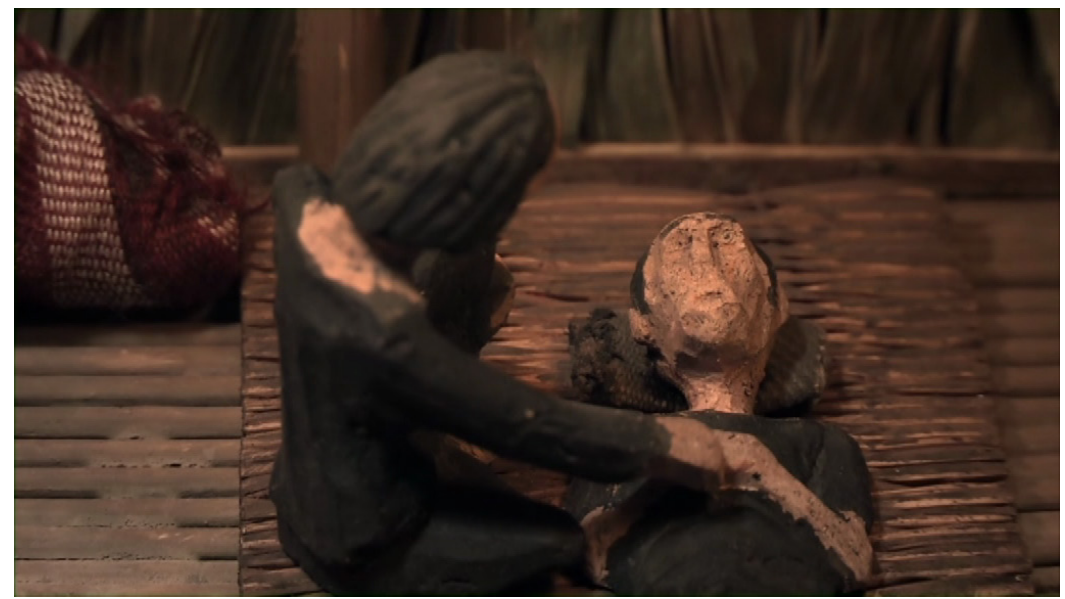

Figure 16.

\footnotetext{
${ }^{43}$ Rithy Panh and Christophe Bataille, The Elimination: A Survivor of the Khmer Rouge Confronts his Past and the Commandant of the Killing Fields (New York: Other Press, 2014). In this book, Panh narrates some of the key events that are at the core of The Missing Picture and with almost the same words. The difference is to be sought, first, in the shortening of the text to the strict essential, and, second, in the evocative aspect given by the image.

${ }^{44}$ Rithy Panh, as quoted by Karin Bad, "Rithy Panh's The Missing Picture: A Memory of the Cambodian Genocide," Huffington Post, April 1, 2014, accessed October 29, 2017, https://www.huffingtonpost.com/karin-badt/rithy-panhs-themissing-p b 5068106.html. Karin Bad considers the act of interring the father and his mourning a metaphor for the film as a whole.
} 


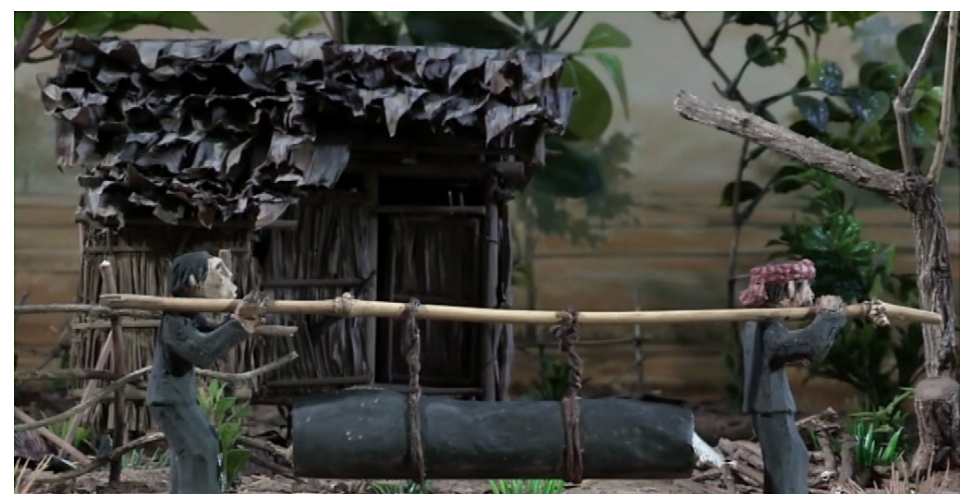

Figure 17.

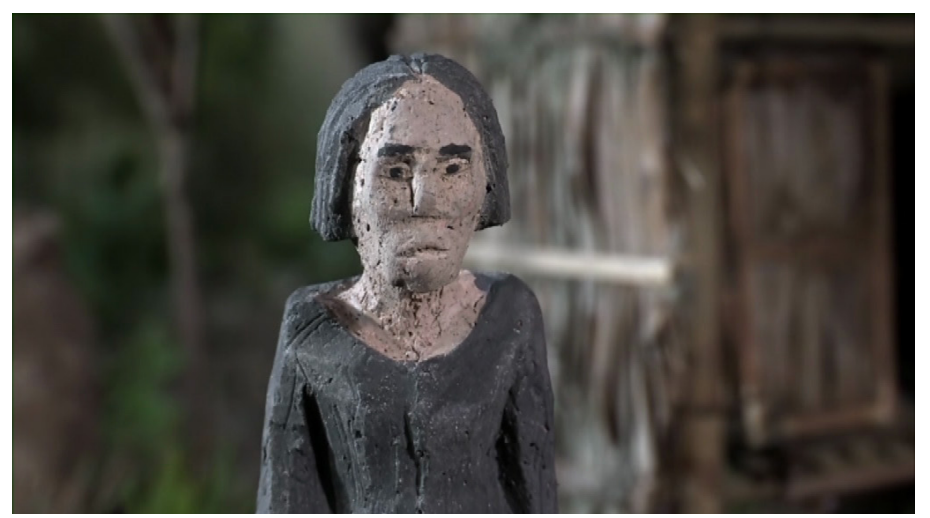

Figure 18.

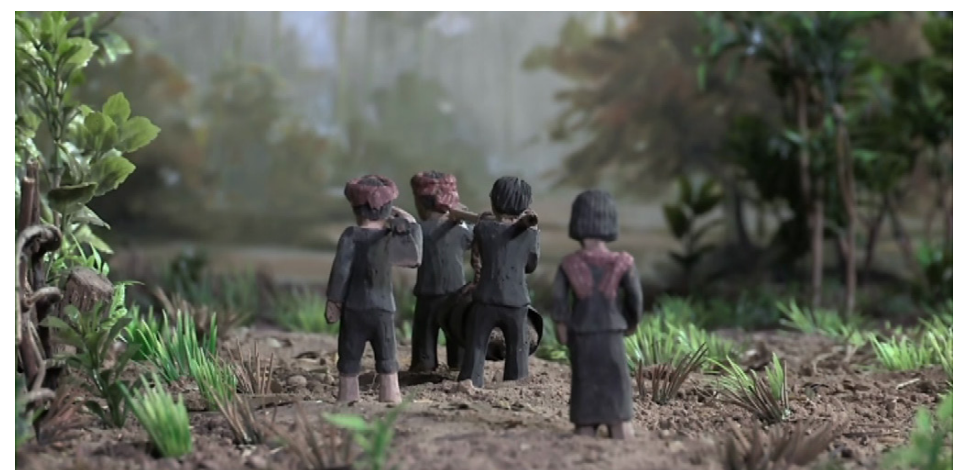

Figure 19.

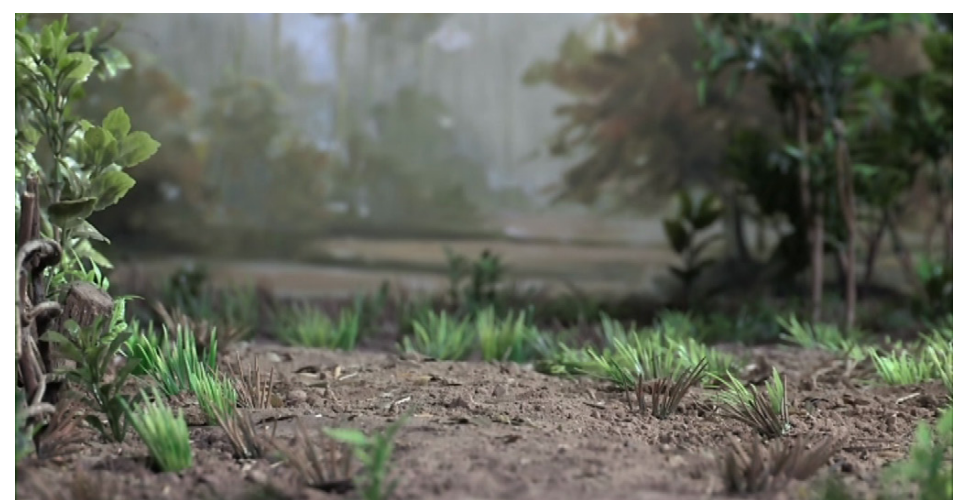

Figure 20. 


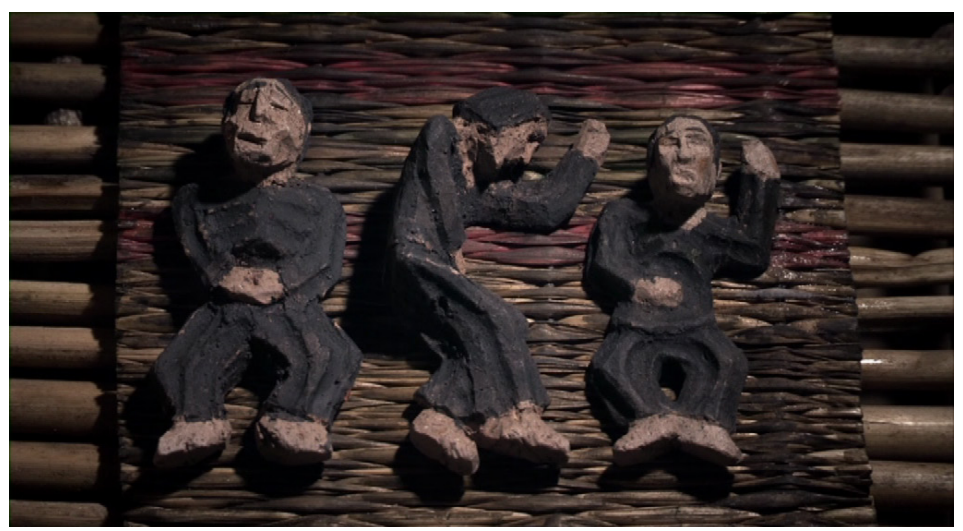

Figure 21.

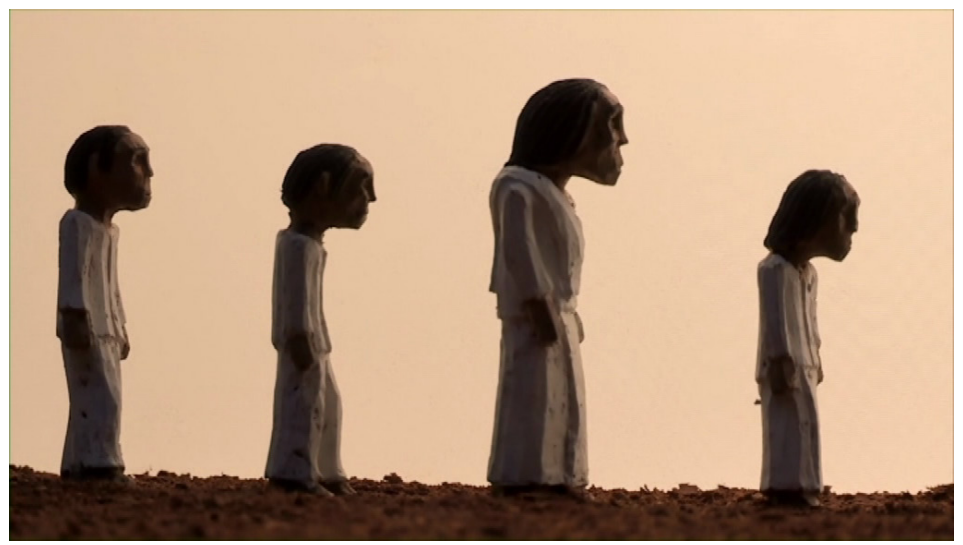

Figure 22.

These images of mourning give way to another film strategy to provide imagery for the passing away of his cousin. She had been discovered stealing corn by the Khmer Rouge guards and her mother, making the repressors language her own perhaps to prevent a deadly threat to the entire family, admonished her: "we are not thieves (...), we are proud people." In hearing these accusatory words against the infant, the young Rithy delves into bewilderment and recounts the night of agony and the inevitable dénouement: "In the night the child eats salt. Her teeth grind. (...). She slept beside me with her swollen belly and her fixed eyes. She was sighing. She called her mother, she called her father and then she kept silence. And we buried her."

After this stark and denuded style, Panh's voiceover ends expressing his wish to reject the picture that clung to this memory: "I don't want to see this picture of hunger any more. So, I show it to you." The passage is fairly obscure, for the image haunting the narrator is, according to his own words, an inner picture, but the one he offers us is by no means the one he refuses to contemplate. Rithy Panh composes his scene in the following way: inside a hut, the figurine representing the dying girl lies on a wooden bed; deep in the night, she passes away. Nothing in the scene attests the visual and aural details the narrator refers to as unforgettable signs hooked to his memory: the stomach bloated by hunger, the grinding of teeth, the plaintive moan in search of her parents, her sighing. The inert figurines give a strange sober aspect to these sentiments conveyed by the intimate voice. Meanwhile the image is circumscribed to procuring the setting for this interminable night and for the wailing that ensues. As if there were no image capable of capturing this nightmare.

Then, in lieu of the omitted image a scene intrudes: on the corpse of the small curled-up figure, a hand drapes a white cloth, insinuating a shroud. This gesture gains relevance precisely because of its naivety; in fact, it is so coherent with the infantile setting that one would say that the hand slips a gauze bandage over the figure, so as to cover a simple wound. The most surprising effect is still 
to come though: over this compassionately shrouded corpse an old family photo is superimposed. It represents a retouched kitsch-like photograph of three "flesh and blood" children posing in a childhood setting. The filmmaker thus introduces a photo of past happiness where now there is only sorrow. We may wonder what the missing picture is in this passage: the one the filmmaker has avoided, but somehow bestows on us? Hardly, since between the image not given and the one of the shroud a recovered childhood emerges as a sort of resurrection not only of the little girl, but of a vanished world. This is, ultimately, an image of redemption. The rest of the children, resumes the narrator, would soon be dead too. The colorful and vivid picture of brothers and sisters who perished in the Khmer Rouge hell triggers the most original metaphor of freedom: the figures of the three children are projected into the skies where they fly freely, liberated from the threats of the earth, as if in a childhood dream. Strictly speaking, it is not a redemptive image; it is redemption through an image.

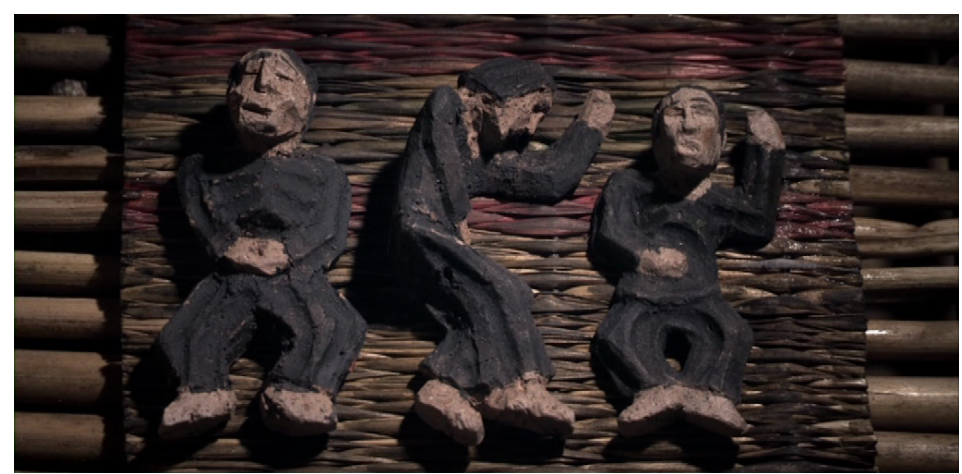

Figure 23.

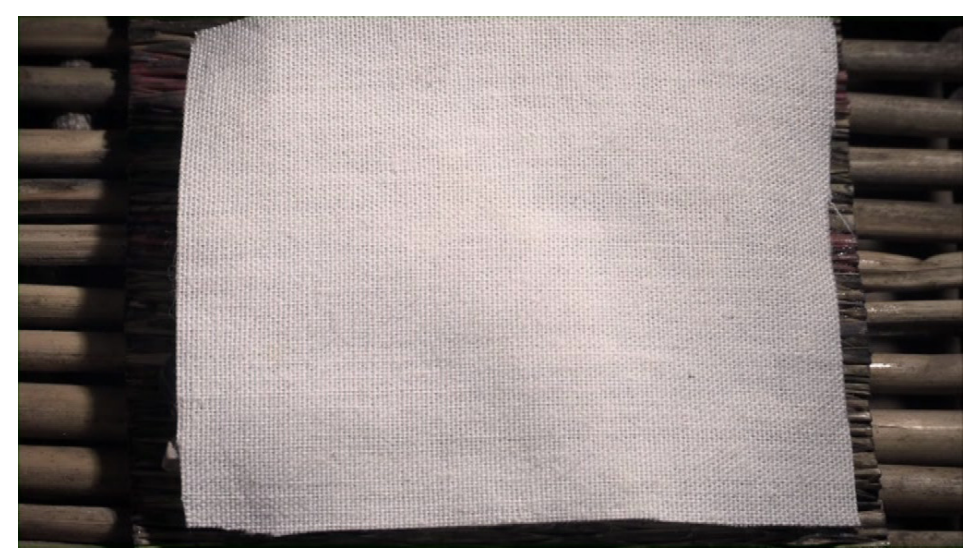

Figure 24.

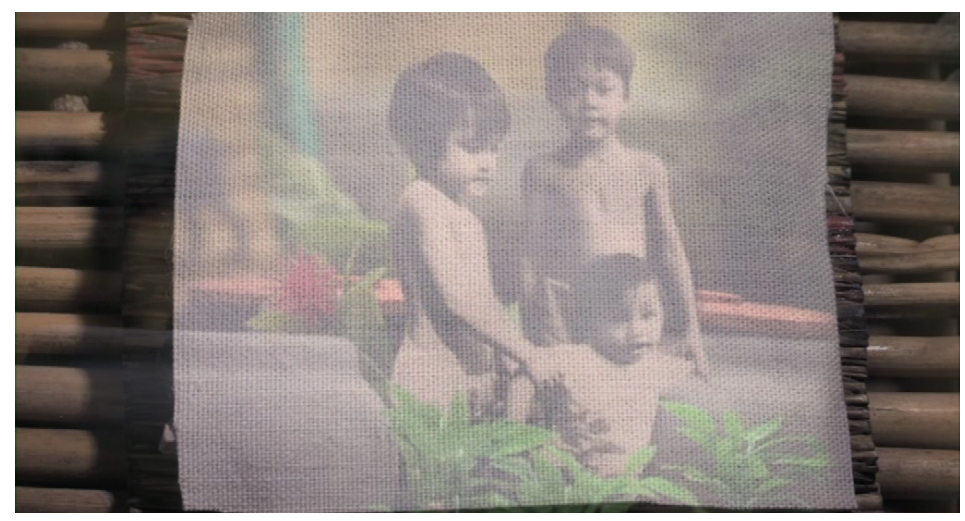

Figure 25. 


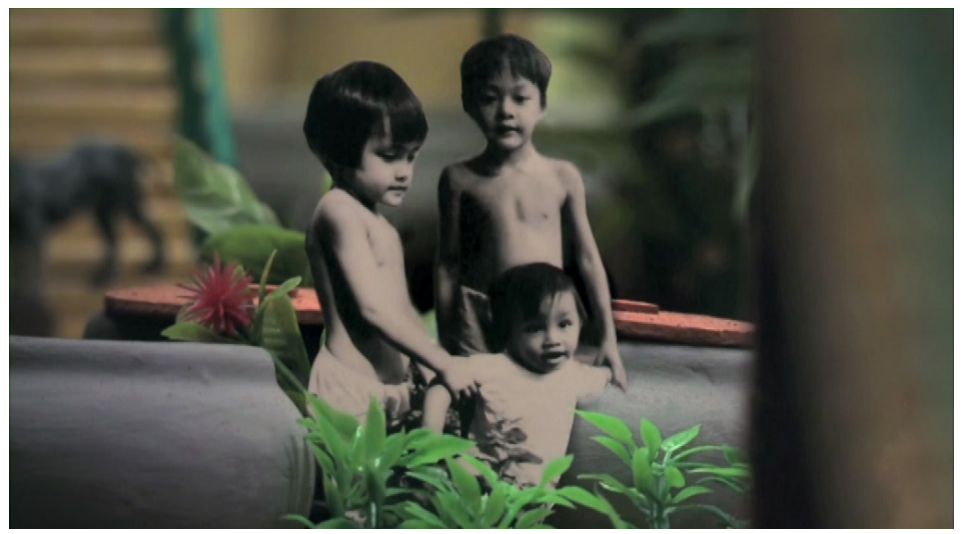

Figure 26.

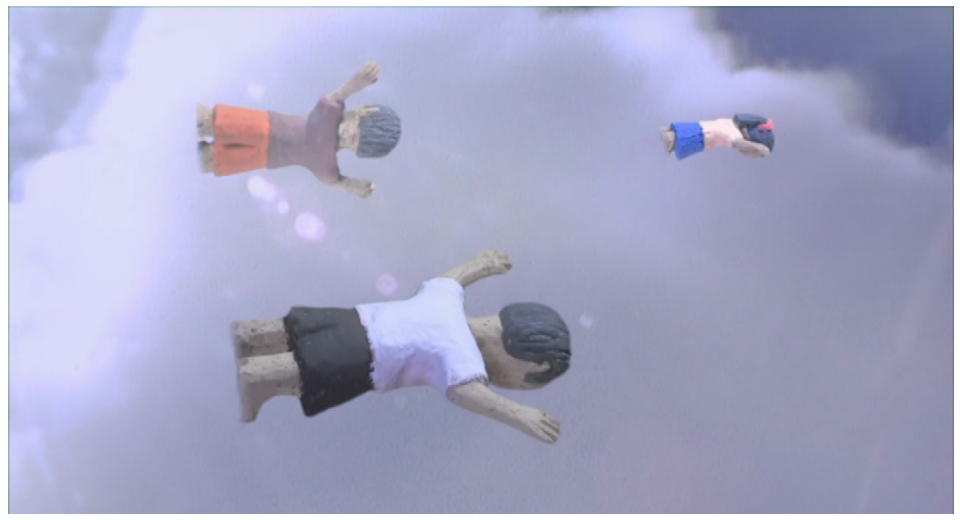

Figure 27.

\section{Plenitude, Syncretism, Compulsion}

As the reader must have concluded from what has preceded, throughout The Missing Picture, images are addressed as a problem, never as evidence. Accordingly, any image, whatever its source, ends up raising skepticism and mistrust, revealing itself as fatally inconsistent with its aim of giving solid ground to memory. After his mother's death, the narrator comprehends his inescapable loneliness and the film shows scenes of this lost infancy as a kind of unattainable: home, kitchen, garden, family gathering. However, these emotive settings tinted with nostalgia appear as inner images. On other occasions, Panh ventures to use his analytical mind to explore the Khmer Rouge's visual output, these images fabricated to create misery. He clings to the hope of deciphering the great lie they contain by reading between the lines and disclosing symptoms of the suffering they have been built on. Another genre of images created by Rithy Panh shows his adult body wandering in the countryside in search of the child he once was: a vain enquiry for which the filmmaker avails himself of the stylistic device of showing his out-of-focus silhouette while a child in play is clearly seen in the background and vice versa in the reverse shot. Panh's refusal to use depth-of-field, maintaining both characters within focus, represents the failed encounter between these two stages of a man's life. In brief, there is no point in searching for a coherent pattern to address the missing picture. However, all the genres of images summoned up have something in common, namely: the compelling search they are born from. All in all, for Rithy Panh, who perceives the surrounding world as inconsistent, any image is condemned to remaining a symptom of distress, the ultimate crystallization of a failure. 


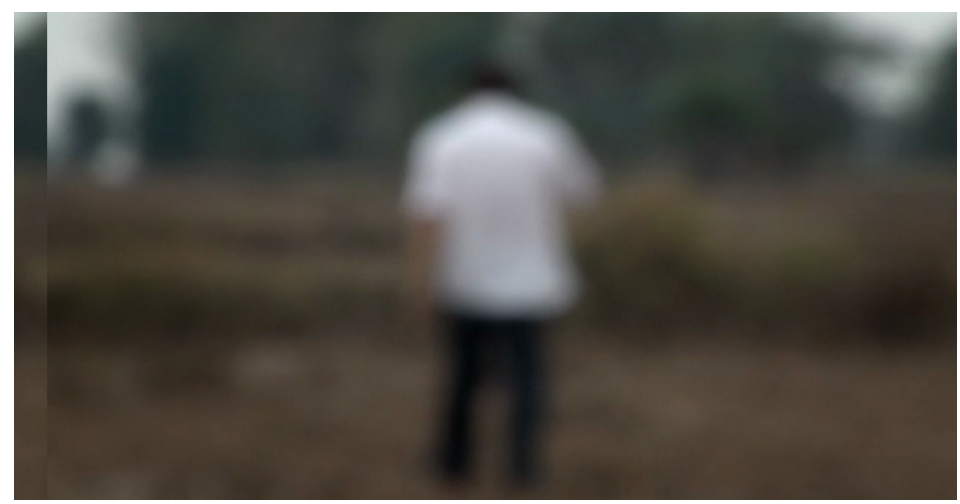

Figure 28.

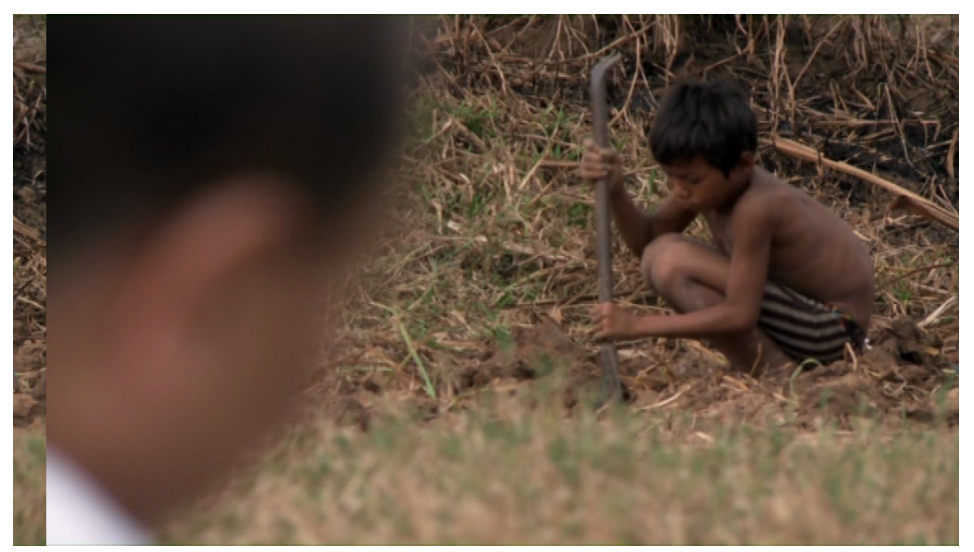

Figure 29.

\section{Repetition Compulsion: When the Narrative Fails}

From such a dramatic context emerges one of the most unsettling sequences of the film, which combines the stillness of the figurines with animation effects. The event evokes one of the last passages in Panh's memoirs from the Khmer Rouge period: sole survivor in the family, the young Panh is assigned to bury the corpses of his own in a mass grave. Condensing this routine activity, the narrator vacillates between his position as a witness and his primary identification with the dead in such a way that he fantasizes with being one of them. It is at that point that the filmmaker's voiceover recovers the idea of missing picture:

There are many things a man should not see or know. And if he saw them it would be better for him to die. But if one of us sees these things or knows them, then he must live to tell about them.

Every morning I used to work over the pit. My shovel bumped into bones and heads. Earth is never enough. I'm the one who is going to get killed or it's already done.

Of course, I did not find the missing picture. I looked for it in vain. A political movie has to discover what it invented. So, I created this picture, I watch it, I cherish it. I hold it in my hand as people do with a beloved face. This missing picture now I give it to you, so that it doesn't stop looking for us. ${ }^{45}$

${ }^{45}$ Panh, The Missing Picture. 
The passage is highly intricate, due to its twofold content: in the first part, the narrator describes the sordid task he accomplished while experiencing everyday death; in the second he takes up the leitmotiv of the missing picture and addresses the spectator in an intimate mood to impress upon them as the final recipient of the metaphorical picture he has invented. Surprisingly enough though, the text cited above is contradicted by the flow of images. At the bottom of the trench lies a rigid figurine. Onto this, spadesful of earth fall, which little by little cover the body completely. Then, as soon as the small figure is swallowed by the earth, an optical animation effect unearths it again, as if the image undoes the work done. The impression we get from this mechanism is that the act of burying the body turns into a cyclical process, eternal, impossible to consummate, but also impossible to escape from. Once again, this potent metaphor emerges as an attempt to give shape to something that resists being put into images; something which, despite being action, turns on itself incapable of breaking free from the circle and reaching an end. The resulting effect is an inner collage-like image that remains stuck in what Sigmund Freud called the "repetition compulsion," that is, an automatism of the human psyche derived from a traumatic experience that makes an image repeat itself over and over again. It is no coincidence that Freud saw in this compulsive mechanism the core of what he termed the death drive. ${ }^{46}$

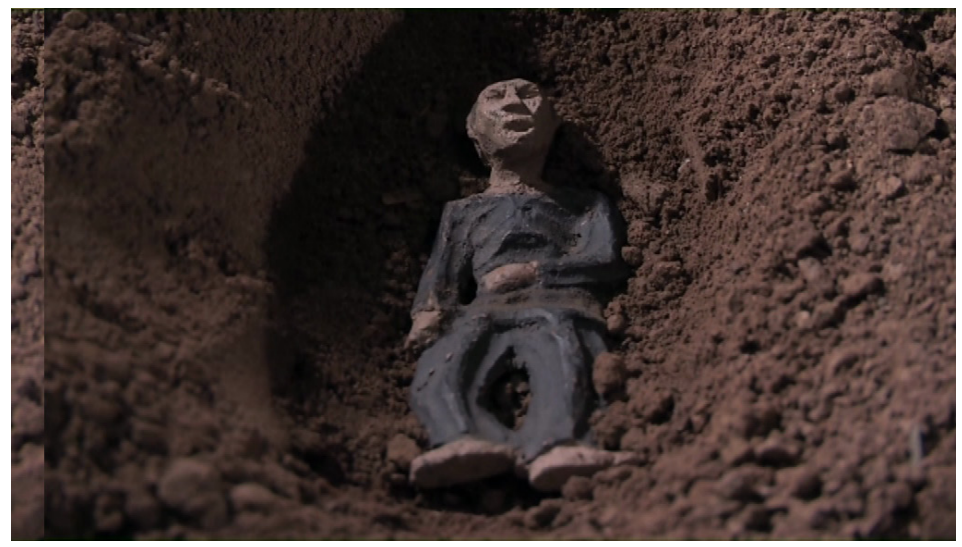

Figure 30 .

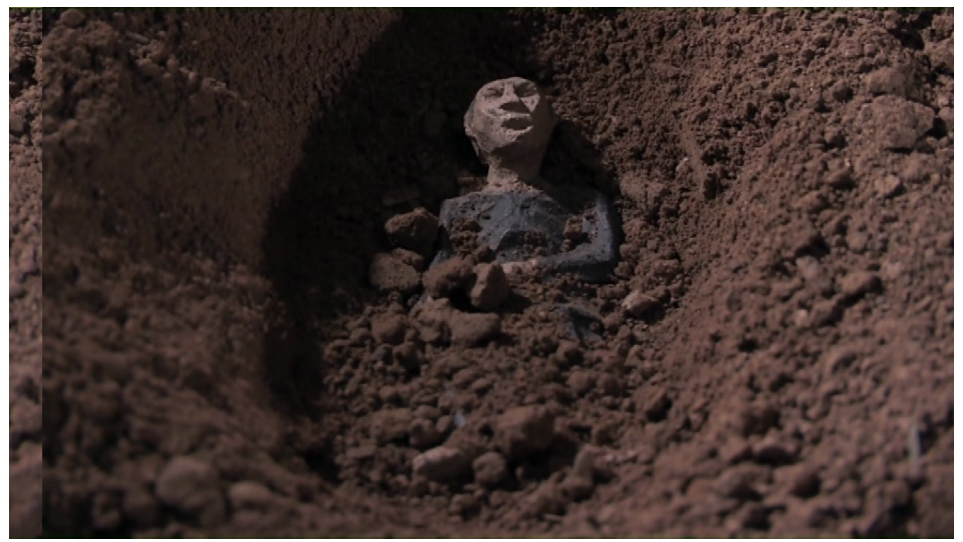

Figure 31.

\footnotetext{
${ }^{46}$ This Freudian notion was speculatively formulated in the seminal text "Beyond the Pleasure Principle," Sigmund Freud, The Standard Edition of the Complete Psychological Works of Sigmund Freud, trans. James Strachey, in collaboration with Anna Freud, vol. XVIII (1902-1922), (London: The Hogarth Press and the Institute of Psychoanalysis, 1955), 7-64. In that edition, the German term Wiederholungszwang is translated as "compulsion to repeat."
} 


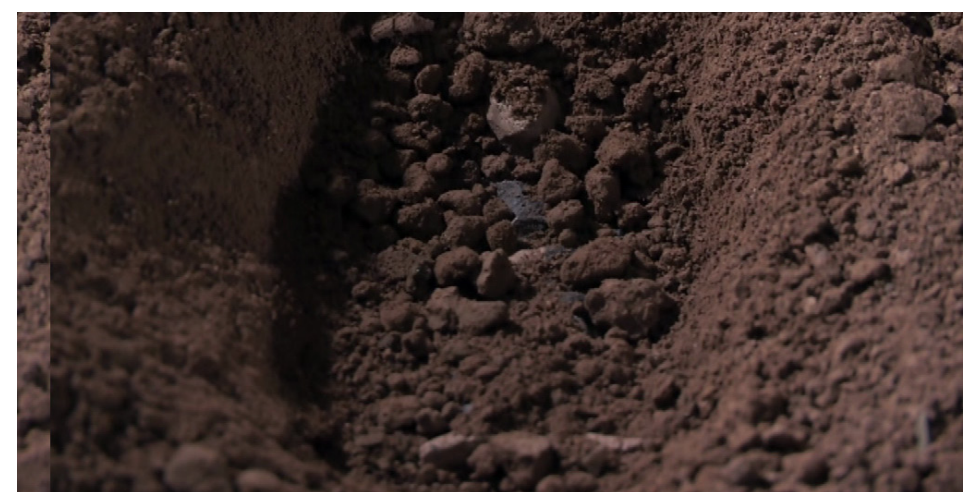

Figure 32.

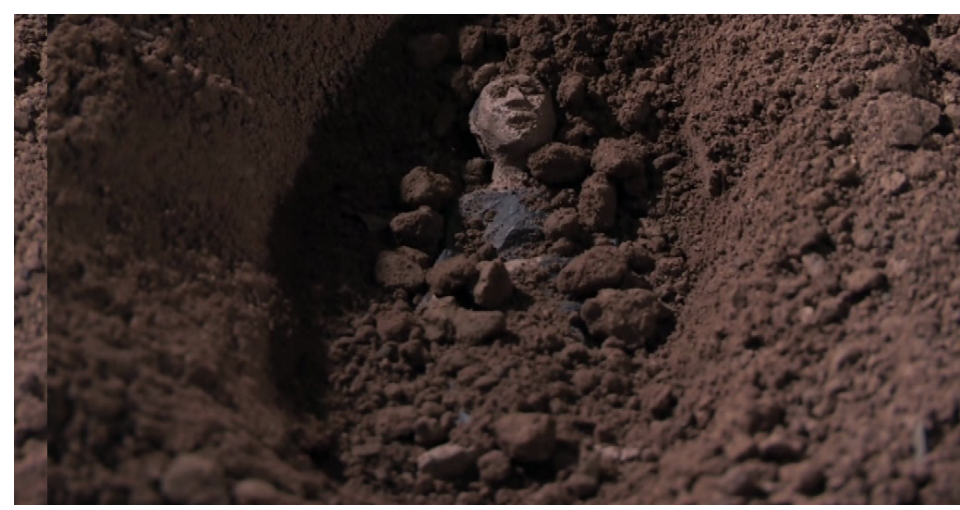

Figure 33.

In such a discursive context, the distancing effect produced by employing figurines becomes doubly destabilizing, as it deactivates realism and yet renders empathy extremely difficult. Nevertheless, the image that the filmmaker offers us as guardian angels at the end of the journey is not the one of the burial, but the one of the shining sea bursting onto the screen, which was associated with anxiety, with its green blue waves and shimmering light that floods the frame. This sequence raises a latent issue in our article the one of trauma. And of course, this is no minor matter. Arguably, the trauma discourse could be productive for the analysis of other sequences of The Missing Picture. However, I am somewhat reticent to engage in the application of this terminology to an artwork in which the mediations (linguistic, of course, but also visual, like set design, script, editing) are so abundant.

\section{Conclusions}

As stated earlier, the Rithy Pahn's film title -The Missing Picture- inevitably begs the question of identification, as if it were a riddle. However, in following this path, the analyst soon gets disoriented in a jungle of heterogeneous images regarding genre and subjective quality. The reason for that lies in the fact that the absence of images is only perceived as such at the instant an expected image fails to make an appearance, leaving the retrospective sensation of an enormous emptiness. This fracture, which is felt by the narrator and passed over to the viewer is ultimately Panh's personal response to the question of the non-representable as a warning and a conceit.

We must conclude that in the way Rithy Panh addresses the problem, the missing picture is structural, not accidental. ${ }^{47}$ This signifies the acknowledgment of a paradoxical failure in telling his biography in images; paradoxical because the filmmaker not only succeeds in recounting his

${ }^{47}$ Sylvie Rollet, in her implicit dialogue with Didi-Hubermann, argues that the lack has the power of suggest an image

("puissante imageante"), “Malgré tout... l'image manque", Cinema \& Cie XV, no. 24 (2015), 95. 
painful experiences, but links them inextricably with the catastrophe which devastated his country. Consequently, the missing picture cannot be identified as a lost picture, since it has no actual form, but constitutes a missing link which remains absent. This is perhaps the reason why the journey results in an unfathomable state of melancholia. And there are good reasons why Rithy Panh would have avoided realistic images to represent personal trauma and social catastrophe together. We could venture that the rejection of analogical images, resorting to animation, the preference for collage, and the original use of figurines in The Missing Picture all point to a search for the intricate and nightmarish picture. All in all, if the vicious circle we are engulfed in through the image of a never-ending burial cycle points to the death drive, that of the sea suggests anxiety and suffocation, for in this last image the object floods the frame with bright hyperbolic images that defy framing, revolving images that never reach an end. Both unequivocally prove that the crucial image is as longed for as it is condemned to be forever missing.

\section{Acknowledgements}

I would like to thank the respective directors, Chhay Visoth, Youk Chhang and Rithy Panh for providing access to the material, as well as Helen Jarvis for facilitating access to the Tuol Sleng archives. I am also grateful for the enlightening conversations in New York with Deirdre Boyle in the Winter-Spring 2017 and to Stéphanie Benzaquen-Gautier and Anne-Laure Porée for sharing a common project on Tuol Sleng.

\section{Bibliography}

Bad, Karin. "Rithy Panh's The Missing Picture: A Memory of the Cambodian Genocide." Huffington Post, April 1, 2014. Accessed October 29, 2017. https://www.huffingtonpost.com/karinbadt/rithy-panhs-the-missing-p b 5068106.html.

Becker, Elizabeth. When the War Was Over. The Voices of Cambodia's Revolution and Its People. New York: Simon and Schuster, 1986.

Bergström, Gunnar and Hedda Ekerwald. Living Hell. Democratic Kampuchea, August 1978. Phnom Penh: Documentation Center of Cambodia, 2008.

Boyle, Deirdre. "Finding the Missing Picture: the Films of Rithy Panh." Cineaste 28 (2014): 28-32.

Bradshaw, Nick. "Memories of Murder: Rithy Panh on the Missing Picture of Childhood." Accessed November 18, 2017. http://www.bfi.org.uk/news-opinion/sight-sound-magazine/ interviews/memories-murder-rithy-panh-missing-picture.

Caldwell, Malcolm. “Revolutionary Violence in a People's War." Social Scientist, 3, no. 1 (1975): 4352. https://doi.org/10.2307/3516429

Caswell, Michelle. Archiving the Unspeakable. Silence, Memory, and the Photographic Record in Cambodia. Madison: University of Wisconsin Press, 2014.

Chandler, David. Voices from S-21. Terror and History in Pol Pot's Secret Prison. Los Angeles \& London: University of California Press, 1999.

Dargis, Manohla. "Returning, in His Own Way, to the Killing Fields. 'The Missing Picture,' Rithy Panh's Look at 1970s Cambodia." New York Times, March 18, 2014.

Didi-Huberman, Georges. Images In Spite of All. Chicago: Chicago University Press, 2008.

Duffaud, Lisa. "Rithy Panh: L'image manquante, 2013 -CR de film de lecture." Indomémoires, April 3, 2015. Accessed November 19, 2017. https://indomemoires.hypotheses.org/17375.

Dunlop, Nic. The Lost Executioner. A Journey into the Heart of the Killing Fields. New York: Walker Publishing Company, 2006.

Ekchaiser, François. "Rithy Panh vit dans la mort, c'est un rescapé, Christophe Bataille écrivain." Télérama, September 10, 2013. Accessed November 17, 2017. http://www. telerama.fr/television/rithy-pan-vit-dans-la-mort-c-est-un-rescape-christophe-batailleecrivain,103199.php.

Fawthrop, Tom and Helen Jarvis. Getting Away with Genocide?: Elusive Justice and the Khmer Rouge Tribunal. London \& Ann Arbor: Pluto Press, 2004.

Freud, Sigmund. "Beyond the Pleasure Principle." In The Standard Edition of the Complete Psychological Works of Sigmund Freud, translated by James Strachey, in collaboration of Anna Freud, vol. XVII, 7-64. London: The Hogarth Press \& the Institute of Psychoanalysis, 1955. 
Hamers, Michelle Q. “Do Nothing, Sit Still, and Wait for My Orders. The Role of Photography in the Archive Practices, Historiography, and Memory of Democratic Kampuchea 19751979." Unpublished Thesis, March 2011.

Hildebrand, George and Gareth Porter. Cambodia. Starvation and Revolution. New York \& London: Monthly Review Press, 1976.

Hinton, Alex. Man or Monster? The Trial of a Khmer Rouge Torturer. Durham: Duke University Press, 2016. https://doi.org/10.1215/9780822373551

Huyssen, Andreas. "Of Mice and Mimesis: Reading Siegelman with Adorno." New German Critique 81, Dialectic of Enlightenment (2000): 65-82.

John. "Cambodian Ghost City in 1978- Phnom Penh Emptied of 2 Million People." Wonderland 1981 (blog), October 25, 2012. Accessed November 18, 2017. https://wonderland1981. wordpress.com/2012/10/25/cambodian-ghost-city-in-1978-phnom-penh-emptied-of-2million-people/.

Lacouture, Jean. “The Bloodiest Revolution." The New York Review of Books, March 31, 1977, 42F.

Lê, Việt. "What Remains: Returns, Representation, and Traumatic Memory in S-21: The Khmer Rouge Killing Machine and Refugee." American Quarterly 66, no. 2 (2014): 301-332. https:// doi.org/10.1353/aq.2014.0028

Levi, Primo. Survival in Auschwitz. The Nazi Assault on Humanity. New York, Oxford, Singapore, Sydney \& Toronto: Macmillan, 1986 [1948]).

Maguire, Peter. Facing Death in Cambodia. New York: Columbia University Press, 2005. https://doi. org/10.7312/magu12052

Morris, Errol. Believing is Seeing. Observations on the Mysteries of Photography. New York: Penguin, 2011.

Nath, Vann. A Cambodian Prison Portrait. One Year in the Khmer Rouge's S21. Bangkok: White Lotus, 1998.

Panh, Rithy, director. Bophana: A Cambodian tragedy. Cambodia \& France: Catherine Dussart Productions (CDP), 1996. 59 min.

---------, director. Duch: Master of the Forges of Hell. Cambodia \& France: Catherine Dussart Productions (CDP), 2011. 103 min.

---------, director. S-21: The Khmer Rouge Killing Machine. Cambodia \& France: Institut National de l'Audiovisuel (INA), 2003. $101 \mathrm{~min}$.

--------, director. The Land of Wandering Souls. Cambodia \& France: Institut National de l' Audiovisuel (INA), 2000. $100 \mathrm{~min}$.

---------, director. The Missing Picture. Cambodia \& France: Catherine Dussart Productions (CDP), 2014. Film

Panh, Rithy and Christophe Bataille. The Elimination. A Survivor of the Khmer Rouge Confronts his Past and the Commandant of the Killing Fields. Translated by John Cullen. New York: Other Press, 2014.

---o-. L'image manquante. Paris: Bernard Grasset, 2013.

Panh, Rithy, et al. Vann Nath, Tribute. Phnom Penh: Bophana Center, 2013.

Phay, Soko. "Missing Images of Genocide and Creation in Cambodia." Journal of Literature and Trauma Studies 4, no. 1-2 (2015): 87-98. https://doi.org/10.1353/jlt.2016.0003

Munro, David, director. Year Zero: The Silent Death of Cambodia. United Kingdom: Associated Television (ATV), $1979.50 \mathrm{~min}$.

Ponchaud, Francois. Cambodia Year Zero. New York: Reinhardt and Winston, 1978 [French original from 1977]).

Rollet, Sylvie. “Malgré tout... l'image manque." Cinéma and Cie XV, no. 24 (2015): 93-102.

Romney, Jonathan. "Film of the Week: the Missing Picture." Film Comment, March 20, 2014. Accessed October 29, 2017. https://www.filmcomment.com/blog/film-of-the-week-themissing-picture.

Sánchez-Biosca, Vicente. "Perpetrator Images, Perpetrator Artifacts: The Nomad Archives of Tuol Sleng (S-21)." Cinema E Cie. International Film Studies Journal XV, no. 24 (2015): 103-116.

Schanberg, Sidney. "Cambodia Reds Are Uprooting Millions as They Impose a 'Peasant Revolution."' The New York Times, May 9, 1979, 1 and 15. 
Sihanouk, Norodom, director. Apsara. Cambodia: Khemara Pictures, 1966. 150 min.

Thompson, Ashley. "Forgetting to Remember, Again: On Curatorial Practice and 'Cambodian Art in the Wake of Genocide."' Diacritics 41, no. 2 (2013): 82-109. https://doi.org/10.1353/ $\underline{\text { dia.2013.0009 }}$

Troeung, Y-Dang and Madeleine Thien. "To the Intellectuals of the West: Rithy Panh's The Elimination and Genealogies of the Cambodian Genocide." Topia: Canadian Journal of Postcolonial Studies no. 35 (2016): 155-171.

Vitorovic, Nikola. "Kampučija' 78." Filmed [1978]. YouTube video. Posted [June 2011]. Accessed November 19, 2017. https://www.youtube.com/watch?v=BjpHZClAGbU. 